\title{
CAPTURING ECONOMIC RENTS FROM RESOURCES THROUGH ROYALTIES AND TAXES*
}

\author{
Jack Mintz and Duanjie Chen ${ }^{\dagger}$
}

\section{SUMMARY}

Oil price fluctuations, concerns over the division of resource revenues, and unconventional oil and gas developments are forcing governments to confront the same issue: how to design optimal royalty and corporate tax systems that bring in a publicly acceptable share of revenues without discouraging private investment.

This paper surveys tax and royalty systems across six countries, as well as four US states and five Canadian provinces, offering concise analyses of their strengths and shortcomings to describe the best and simplest approaches to both.

As in a public-private partnership, government owns the resources and allows private agents to maximize the rents resources generate. An optimal royalty system will thus be rent-based, ensuring that both owner and agent obtain maximally competitive returns so that each has incentives to continue the partnership. Such a system will also be simple, making compliance easy, manipulation difficult, and risks affordable. And it will be stable, instilling in the private sector the confidence needed to invest for the long term.

As for corporate income taxes, they should be neutral across business activities, and applied at equal effective rates on economic income, to avoid distorting market forces through subsidies or needless complexity.

A clean rent-based tax that allows all costs incurred by producers to be expensed or carried over, along with a corporate income tax system shorn of many of the preferences that negatively affect business activity, should be the way forward for any government looking to update their fiscal regimes for the 21 st century.

\footnotetext{
*This research was financially supported by the Government of Canada via a partnership with Western Economic Diversification.

† Jack Mintz is the Palmer Chair of Public Policy and Duanjie Chen is a Research Fellow at The School of Public Policy. Prepared for the PWC Tax Policy Roundtable at The School of Public Policy, University of Calgary, February 29, 2012. We wish to thank Philip Daniel, Tom Huffaker, Greg Melchin, Angelo Toselli, participants of the Roundtable and an anonymous referee for excellent comments that have materially improved this paper. We also wish to thank Stephen Richardson and David Sewell for their comments.
} 


\section{SAISIR LA RENTE ÉCONOMIQUE DES RESSOURCES AU MOYEN DE REDEVANCES ET DE TAXES*}

Jack Mintz et Duanjie Chen ${ }^{+}$

\section{RÉSUMÉ}

Les fluctuations du prix du pétrole, les préoccupations sur la division des revenus des ressources et l'exploitation non conventionnelle du pétrole et du gaz forcent les gouvernements à se poser la même question : comment concevoir des systèmes de redevances et d'impôts qui offrent des revenus acceptables pour la population sans décourager l'investissement privé?

Cet article porte sur les systèmes d'impôts et de redevances dans six pays, quatre États américains et cinq provinces canadiennes, et propose des analyses concises des forces et des faiblesses de chacun dans le but de définir les approches les plus simples et les plus efficaces.

Comme dans les partenariats publics-privés, les ressources appartiennent au gouvernement qui permet à des exploitants privés de maximiser les rentes que ces ressources génèrent. Par conséquent, un système de redevances optimal est axé sur les rentes pour que le propriétaire et l'exploitant obtiennent tous deux d'excellents rendements qui militent en faveur du maintien leur association. Un tel système est simple, ses règles sont faciles à suivre, on peut difficilement le manipuler et les risques sont abordables. En plus, il est stable et inspire aux intervenants du secteur privé la confiance dont ils ont besoin pour investir à long terme.

En ce qui a trait aux impôts des sociétés, ils doivent être neutres pour l'ensemble des activités d'entreprise et être appliqués à des taux réels égaux sur le revenu économique pour éviter de fausser le marché par des subsides ou une trop grande complexité.

Un gouvernement qui envisage d'améliorer son système fiscal p our l e 2 le s iècle d evrait opter pour un impôt bien défini axé sur la rente, qui permet à tous les coûts assumés par les producteurs d'être passés en charges ou reportés, conjugué à un régime fiscal des entreprises amputé de bon nombre des avantages qui se répercutent négativement sur les affaires.

Cette recherche a été soutenue financièrement en partie par le gouvernement du Canada via Diversification de l'économie de I'Ouest Canada.

Jack Mintz est titulaire de la Chaire Palmer d'études des politiques publiques et Duanjie Chen est chercheuse à l'École de politiques publiques. Préparé pour la table ronde sur la politique fiscale de PWC à l'École de politiques publiques, Université de Calgary, le 29 février 2012. Nous souhaitons remercier Philip Daniel, Tom Huffaker, Greg Melchin, Angelo Toselli, les participants à la table ronde et un lecteur anonyme pour leurs excellents commentaires qui ont sensiblement amélioré cet article. Nous remercions aussi Stephen Richardson et David Sewell pour leurs remarques. 


\section{INTRODUCTION}

Owing to the unpredictable fluctuation of oil prices over recent years, the debate on and resulting reform of the fiscal regimes targeting the oil industry around the world has heated up and yet remains understandably unsettling. Examples demonstrating such unsettling patterns include the most recent reforms in Canada (Alberta) and Australia.

Further, new unconventional sources of oil and gas deposits have become economically feasible to produce, such as the oil sands and shale gas. Governments with access to new revenue sources are developing royalty systems that capture rents without unduly discouraging extractive resource developments.

This paper is aimed at searching for the optimal fiscal regime towards the oil and gas industry by comparatively evaluating such regimes in several major oil-producing countries. This is a daunting task given that risks in international comparisons of fiscal regimes concerning the oil and gas industry are abundant, among which "misinterpretation of individual fiscal regimes" might be the most dangerous. ${ }^{l}$ We therefore limit our study only to those regimes for which the description is unambiguously provided on government websites, so that our interpretation of a given fiscal regime may be relatively easy to verify. With this limitation, our study covers only the following six countries: Australia, Brazil, Canada (five provinces), Norway, the United Kingdom and the United States (four states).

Many other countries that are rich in oil and gas resources are excluded from our study. They include Iraq, Kuwait, Mexico and Saudi Arabia, which together account for over 30 percent of world output. Production of oil and gas in these countries is exclusively undertaken by national oil companies or even by the government itself. ${ }^{2}$ Therefore, for non-government-owned oil industry in these countries, there is no fiscal regime that is sufficiently transparent to be compared to that elsewhere.

In our study, we look at the impact of both taxes and the royalties of various fiscal regimes on investment decisions. It is critical to understand the nature of potential economic effects since resources themselves do not move, and therefore royalties and taxes on economic rents income in excess of returns paid to attract capital and labour for resource development - are a more efficient form of taxation. However, capital and profits, which are particularly mobile, do move, so royalties that discourage investments by resource companies could result in less development (with the resources being left for future extraction).

\footnotetext{
I See Phillip Daniel, et al, "Evaluating Fiscal Regimes for Resource Projects: An Example from Oil Development," in The Taxation of Petroleum and Minerals: Principles, Problems and Practice (Routledge Explorations in Environmental Economics), May 10, 2010, in which the stated risks include "misinterpretation of individual fiscal regimes, differences in treatment of indirect taxes, inconsistency of ring-fencing rules, issues of incremental investments, and interaction between host country tax systems and home country systems of investing companies."

2 Ibid.
} 
It is becoming imperative, however, for oil-producing provinces in Canada and elsewhere to have a closer look at the structure of royalty regimes in order to update them for the $21 \mathrm{st}$ century. Most oil-producing countries in the industrialized world, including Australia, Norway and the United Kingdom, have moved towards net-profit or rent-based regimes for oil and gas production. Under a rent-based regime, current and capital costs are deductible from revenues (with any unused deductions being carried forward at the appropriate interest rate, reflecting the fact that the government shares returns, risk and investment costs with the private sector). Despite some important limitations to rent-based regimes (particularly with respect to information on costs), a rent-based royalty has worked well in oil sands production in Alberta. We argue that this royalty structure, with the exclusion of its price-sensitivity, is an appropriate rent-based payment for other jurisdictions to consider as a rent-collection device.

Another critical issue is the tax treatment of oil and gas industries under the corporate income tax. Corporate taxation has become a focus in recent years since governments are considering whether to remove so-called fossil fuel "subsidies." We evaluate the neutrality of the corporate income tax provisions in terms of applying similar tax burdens across industries, including the tax treatment of intangible expenditures such as research and exploration. We argue that the corporate income tax should apply to a tax base reflecting economic income, except in those cases in which firms are unable to fully appropriate returns from discovery investments (such as research and exploration). In this case, discovery might be provided a more favourable treatment, although we do not estimate the optimal level of subsidy.

We specifically find that several oil and gas tax and royalty systems discourage investment relative to other industries. This is especially so when considering the interaction between the income tax and the royalty provisions that leads to high tax and royalty burdens on marginal investments, since few royalty structures are strictly rent-based. Thus, fossil fuel subsidies are more apparent than real in several cases. ${ }^{3}$ In other cases, oil investments are provided a more favourable regime for investments, which typically arises from favourable royalty and corporate tax provisions for exploration and development.

This report is developed as follows. In the next section, we discuss the principles underlying an optimal royalty and corporate income tax policy for a government. This is followed by a conceptual discussion of the marginal effective tax and royalty rate (METRR) as it would apply to the oil industry. We then examine the royalty regimes in Canada in comparison with the five oil-producing countries mentioned above, first with a brief description of their statutory provisions, and then a METRR analysis in terms of fiscal impact on the oil industry and the interaction between oil-specific levies (including royalties and rent taxes) and income taxes. The final section concludes our study.

Appendices are provided to describe theoretical derivations (Appendix A), tax and non-tax parameters by jurisdiction as used in our METRR models (Appendix B), and country-specific METRR models (Appendices C - E). 


\section{OPTIMAL ROYALTY DESIGN}

Royalty design is a complex subject since governments around the world extract a share of the rents by using various approaches. These approaches take into account various factors including revenues, investments and information, especially with regard to production costs.

A common royalty is a payment either based on a share of gross output, or revenues of a nonrenewable resource project for the provision of goods or services below market value.

However, the price is not set by the market since royalty rates are set by governments - there is no market-determined royalty rate that is the analog of a market price. Indeed, there is no necessity that governments use royalties as commonly understood to collect a payment as in the private sector. Governments can, and do, use other mechanisms.

In recent years, provinces have been resorting increasingly to net-profit systems, by which costs are deductible in some form in determining the royalty base, rather than a conventional royalty based on a percentage of production revenues. Provincial mining taxes are applied to profits gross of interest deductions. Some provinces have adopted a resource royalty or mining tax based on rents, typically measured as revenue net of current and capital expenditures (an investment allowance is provided to carry forward unused deductions at a rate of interest to preserve the time value of money). In the oil sector the obvious example is the net cash flow tax applied to oil sands, which is a form of rent tax. Provinces also use bonus bids for land tracts to raise revenue. Bonus bids effectively tax rents.

Economic rent arises from non-reproducible (or fixed) factors of production such as entrepreneurship, land and natural resources. It can also arise due to the presence of natural or artificial barriers to entry that generate market power, and special advantages that firms may possess (such as location, patents, etc.). More generally, rent is the surplus value of a resource after all costs, including opportunity costs, are subtracted from revenues arising from the sale of goods and services. Rent is thus measured as the difference between the price at which a resource can be sold and its discovery, extraction, and production costs, including a rate of return on capital that can be obtained by investing in projects with similar risk and scale.

Any tax or levy applied to pure economic rent will not distort the use of capital or other production factors. At the margin, firms employ capital, labour and other factors until the marginal return ${ }^{4}$ on the last unit employed is equal to its economic costs. In economic terms, rents are zero at the margin, negative if too much production takes place and positive if too little rent-earning production is undertaken by the producer. Hence, for marginal decisions investment or otherwise - the rent earned is zero, as returns equal costs in using production factors. A pure rent-based tax will neither discourage nor encourage the investment or production decision, since the levy is neutral in that it does not affect investment and technology decisions.

\footnotetext{
4 More formerly, the marginal return is equal to the marginal gross revenue earned from employing one more unit of
} the factor net of the scarcity value of extracting the resource. 
In most situations around the world, governments are typically owners of the resource (freehold ownership does arise in Canada and the United States, which is not the focus here). The relationship between the government as owner of the resource and the private producer is similar to a public-private partnership. The government is the principal owner and the private company is the agent brought in to maximize the amount of rents that can be generated by the non-renewable resource project. The assessment of royalty policy is based on several critical factors:

- Government ownership: As the owner of the natural resource, the government is entitled to the rents accruing to the project. Some of the rents may be associated with entrepreneurship or land, and therefore accrue to private producers and landowners with the government receiving the remainder.

- Competitive return for private investors: As the agent, the private producer and its investors must be provided a risk-adjusted rate of return on capital that is at least as much as what is available elsewhere to have sufficient incentive to invest in the project. To attract the best producers, the government gives up some of its share of rents. ${ }^{5}$

- Efficiency: The royalty structure should be devised to maximize rents available to both the public owner and the private producer. A rent-based royalty achieves a maximum amount of rents being earned by the public and private partners since production, investment, exploration and development are sufficiently profitable with and without the royalty.

- Simplicity: ${ }^{6}$ The royalty structure should be simple and hence easy to comply with and hard to manipulate. The unique risk associated with upstream oil investment and production does not warrant complexity in royalty design.

- Stability: Royalty regimes can exacerbate uncertainty if they are not properly designed. When resource prices are high, governments may not feel they receive their share of rents, resulting in royalty hikes. When prices fall, the governments might look at providing new incentives, finding them too rich once the economy recovers. To minimize political risk for private investors, it is appropriate for the government to choose a royalty structure that provides both sufficient incentive for investment and revenues for government without changing public policy on a continuous basis.

These five principles are simple to consider for royalty design and lead to a very specific recommendation: the optimal royalty is a rent-based one so as to maximize economic rents.

Nonetheless, there are various other issues that could be considered in designing the optimal royalty system.

5 In principal-agent models, the principal does not know the most cost-efficient producers. It therefore designs a contract to attract the best agent to produce the resource. This requires the government to share some of the rents with the producer.

6 We thank Tom Huffaker for suggesting this additional criterion, which has been one of the well-established criteria for designing and assessing a tax regime in general. 
The first is that a government might wish to reduce extraction if the social discount rate in determining the benefits accruing to future generations is less than the private discount rate for determining profitability. In this case, a rent-based royalty will not be socially efficient since too much production and investment takes place. Therefore, some other sort of mechanism might be used to discourage investment, including regulation or corporate taxation, or through the royalty itself, if a government wishes to have slower development of resources than would be determined by a market. This is very much a political judgement, since social discount rates reflect social or political preferences and are subject to value judgement.

Second, non-renewable resource production can have an impact on the use of clean air, water and land. Royalties could be adjusted to reward good environmental behaviour. On the other hand, other economic instruments are better suited to control the environment, since they are specifically directed at the problem. Examples would be production-related environmental taxes to cost emissions and regulations, and reclamation funds when the mine is terminated (supported by tax-assisted trust rules).

Third, it is critical to recognize that governments not only collect royalties or other specific resource-specific charges; they also collect corporate income taxes, capital taxes and other capital-related levies. These taxes add to investment costs and reduce the return to capital earned by the investor. In some jurisdictions, such as Norway and the United Kingdom, the resource royalty is explicitly recognized as part of the corporate income tax and levied as an additional corporate tax on the industry. In most jurisdictions, however, royalties are treated as separate levies from the corporate income tax. Regardless, any analysis of a royalty system should account for its interaction with the corporate income tax. As shown in Appendix A for interested readers, a rent-based royalty system is not neutral with respect to investment, since the government does not share the corporate tax burden with investors - investments are discouraged as a result when a rent-based royalty is superimposed on a corporate income tax.?

Fourth, a government, in contracting with private producers to extract non-renewable resources, may not have full information about costs of production in determining the rentbased royalty payment. Many governments often use a revenue-based or gross royalty consisting of price- and production-sensitive royalty rates applied to gross production or special drilling credits, arguably as a result of informational deficiencies in measuring costs. Nonetheless, in setting the conventional royalty rate, it is necessary to know something about costs (which is also obtainable under the corporate tax) so the informational requirements are not avoidable.

7 To make the royalty truly rent-based, two adjustments would be needed when royalties are deductible from the corporate income tax. The first is that capital cost and depletion allowances under the corporate tax should be based on the cost of investment net of the government's royalty share of the cost. The second is the provision of an investment tax credit that is needed to offset the grinding down of cost deductions from the rent-based royalty (the credit rate would be equal to the royalty rate multiplied by the corporate income tax rate). Combining the two adjustments, the overall marginal effective tax and royalty rate on capital investments would be reduced in value. 
The rationale for production- and price-sensitive revenue-based or gross royalties lies in the notion of economic rent. By their nature, revenue-based royalties do not constitute a tax on economic rent because they are levied on gross production or revenue, with no deduction for costs. As such, royalties are by their nature distortionary, and indeed discourage investment and production in the oil and gas industry. Higher prices will result in higher rent margins so that revenue-based royalties are adjusted upwards. On a per-unit-of-production basis, a highproduction well will have lower costs than a small-production well. Higher royalty rates on high-production wells (or rather the converse of lower royalty rates on low production wells) are therefore an imperfect attempt to incorporate costs into a gross royalty system and approximate a levy on rent.

In some situations, governments may have so little information about costs that a rent-based royalty is impractical. If royalties are collected well by well, it is administratively costly to collect royalties based on rents that would allow a deduction for well costs. For informational reasons, private landowners would more likely use a revenue-based royalty, since they do not have access to cost data.

In practice, governments have good access to information on costs, since they have the ability to audit financial data provided by companies. Nonetheless, some limitations might be imposed on cost deductions. For example, many rent-based systems do not allow overhead costs to be deducted since a government cannot observe how much these costs can be attributed to the project being developed. Instead, a rough adjustment through an uplift factor on costs might be used.

With rent-based royalties, governments can protect their interests by requiring minimum payments based on revenues; this arrangement is typically found in profit-sensitive royalty systems in Canada and abroad. The minimum royalty does impose some risk on private producers since government shares the upside in profits but not the downside. However, it can be an acceptable trade-off when governments do not have full access to information.

Governments can obtain petroleum revenues on a rent basis in two ways. The first is to auction off the right to explore, develop and extract resources from land. The second is to assess a rentbased royalty on rents or cash flows earned by the resource firm. The first method is an ex ante approach, whereby the revenues are obtained prior to knowledge about the size of the resource pool. The second approach is an ex post approach to collecting rents once the known resource is found and extracted. In many countries, both ex ante and ex post approaches are used to collect government revenues - greater reliance on the ex post reduces revenues from the ex ante approach. For our analysis, both are reasonable approaches to collecting rents.

To conclude, the rent-based royalty system is an appropriate way to collect rents while minimizing economic distortions. 


\section{OPTIMAL CORPORATE INCOME TAX DESIGN}

As reviewed by the Technical Committee on Business Taxation in $1997,{ }^{8}$ the purpose of the corporate income tax is threefold. It serves as a withholding tax on corporate income to shore up personal taxes that cannot be applied uniformly on all sources of income, especially capital gains. It also serves as a withholding tax on income paid to non-resident owners. And finally, the corporate tax is a surrogate payment for the use of public services that are beneficial to the profitability of businesses.

Given these three objectives, the corporate tax should be generally neutral across business activities. This is best achieved by applying the corporate tax at equal effective tax rates on economic income accruing to shareowners given the withholding role of corporate income to ensure that equity income is taxed. Neutrality - similar tax treatment of business activities is an appropriate benchmark against which to assess the corporate income tax.

A caveat to the principle of neutrality is the potential market failures that could arise with respect to the economy-wide impacts of certain forms of business activities. For example, businesses may underinvest in costly research and discovery since they cannot fully appropriate the returns that also accrue to other businesses that do not pay for the costs. Or businesses might overinvest in some activities that cause environmental damage, and their investments should therefore be discouraged by higher effective tax rates on capital. While an argument might be made to adjust corporate tax policies to account for these market distortions, corporate tax policy is not the best mechanism to correct market failures compared to regulations, public expenditure programs and other tax or subsidy remedies.

As a general principle, neutral corporate taxation of the oil and gas industry would imply a similar corporate tax rate on resource profits as other business activities. Pre-production and post-production capital expenditures should be treated similarly. This would imply that capital deductions for investments in real assets should reflect the replacement cost of depreciating and depleting assets. Given that intangible expenditures on exploration and development are incurred prior to the realization of income in later years, such expenditures should be capitalized and written off once reserves are made ready for extraction and income is generated.

As discussed above, exploration expenditures are akin to research, to the extent that such activities are essentially about information and knowledge acquisition. There are typically thought to be spillovers associated with the generation of information and knowledge. These spillovers mean that the information discovered or acquired by one firm generates information, and therefore uncompensated benefits, to others. Without government grants or tax preferences, information and knowledge acquisition would be too low, since businesses do not fully appropriate social returns on their investments. This provides a policy rationale for subsidizing knowledge acquisition, which becomes a typical justification for the R\&D tax credit that is available to all corporations. A similar point may be made with regard to exploration (but perhaps not development) in the resource sector. For example, the discovery (or not) of oil or gas in a particular region most certainly conveys information to other companies that is not

8 Technical Committee on Business Taxation, Report, Department of Finance, Ottawa, 1997, Chapter 1. 
properly internalized. While one can debate the size of these informational spillovers, on their own and in comparison to spillovers from R\&D more generally, it seems indisputable that they exist. Ideally, any subsidy to account for informational spillovers due to either R\&D or exploration should be based upon the size of those spillovers. In reality, the size of spillovers is rarely measurable, such that the only base for subsidy is the size of expenditure itself on research or exploration.

As a final note, Canada and many other countries have provided special tax concessions for research expenditures as well as exploration, both forms of discovery expenditures.

Environmental degradation is typically dealt with by other policies such as regulation and environmental taxation, although some corporate tax preferences are given for investments in environmental cost-reducing technologies.

\section{MARGINAL EFFECTIVE TAX AND ROYALTY RATES (METRRS)}

Using a rent-based royalty as the benchmark, we evaluate the impact of corporate, sales and other taxes on investments in oil and gas. Corporate income taxes, capital taxes and sales taxes on capital purchases clearly affect the investment decision. In this section, we provide a heuristic explanation of the marginal effective tax and royalty rate (METRR), ${ }^{9}$ which is the technical indicator showing the impact of fiscal regimes on investment in the industry.

Conceptually, a business invests in capital until the rate of return on incremental dollars is equal to the cost of capital (at this point no further rents are earned). To measure the effect of taxes and royalties on investment decisions in the oil industry, we calculate the marginal effective tax and royalty rate as the amount of taxes and royalties paid as a percentage of the pre-tax-and-royalty return on capital that would be required to cover taxes, royalties, and the financing of capital with debt and equity. For example, if a business invests in capital at the margin, that yields a pre-tax-and-royalty net-of-risk rate of return equal to 15 percent and, after taxes and royalties, a net-of-risk rate of return equal to five percent, so the METRR is 15 percent minus five percent divided by 15 percent, giving a result of 67 percent. $^{10}$

Risk is incorporated in the analysis by measuring the risk-adjusted rate of return on capital. To the extent that the tax or royalty system shares risks with producers by allowing for refundability of losses, the government provides an implicit deduction for the cost of risk. ${ }^{11}$

9 This discussion is based on J. Mintz and D. Chen, "Taxing Canada's Cash Cow: Tax and Royalty Burdens on Oil and Gas Investments," SPP Briefing Paper, 3(3), The School of Public Policy, University of Calgary, 2010.

10 To be clear, we are not assuming five percent is the after-tax rate of return (net of risk) for a project. The after-tax rates of return are based on a modelling of capital market equilibrium for observable interest rates and equity costs

11

This proposition is well known in the literature, which implies that the risk premium from capital asset pricing models is reduced by the factor one minus the tax rate (see Roger Gordon and John D. Wilson, "Measuring the Efficiency Cost of Taxing Risky Capital Income," American Economic Review, 79(3), 1989, 427-39 and J. Mintz, "The Corporate Income Tax: A Survey," Fiscal Studies, 16(4), 23-68, 1996). In a recent critique of our analysis of the Newfoundland \& Labrador offshore royalty system, it was misunderstood that we had already fully incorporated income risk in our analysis of marginal effective tax rates on resource projects (W. Locke, "Do Newfoundland and Labrador Royalties Fully Subsidize Oil and Gas Investments: An Independent of an Assessment of Claims Made in Mintz and Chen (2010) and Mintz (2010),” The Harris Centre, Memorial University, 2010). 
Many rent-based royalties enable companies to carry forward unused deductions at a rate of interest. This enables companies to preserve the time value of their deductions and moves the system closer to full-loss refundability. Since full-loss refundability implies that governments share income and capital risk with the private producer, it also implies that the appropriate carryforward rate for unused deduction should be a riskless interest rate, such as a long-term government bond interest rate. ${ }^{12}$ This issue has been contentious in some countries where private producers have argued for discount rates that reflect those used for investment project analysis yet the discount rates are too high, since they incorporate risk already shared by the government through loss offsets. This point will be further discussed below, especially with regard to Australian, Newfoundland \& Labrador and Nova Scotia oil and gas investments.

\section{BOX A: A SIMPLE EXAMPLE OF A RENT-BASED ROYALTY}

The rent-based royalty provides a full deduction for current and capital costs. It is neutral with respect to investment decisions, since only revenues in excess of economic costs are subject to the rent-based royalty.

When a loss is incurred, the government could refund the loss at the royalty rate, or alternatively allow the loss to be carried forward at a rate of interest to preserve the value of the deduction as if it were refunded immediately.

To understand the mechanics of both approaches to the rent-based royalty, the following example is provided. In this example, positive rents are earned in that the present value of pre-royalty cash flows (discounted at a five-percent rate) is equal to $\$ 15329$ (if it were a project that was just sufficiently profitable (marginal), it would have discounted cash flows equal to zero).

\begin{tabular}{|c|c|c|c|c|c|}
\hline & Year 1 & Year 2 & Year 3 & Year 4 & Year $5^{(2)}$ \\
\hline Revenues & & & $\$ 10000$ & $\$ 15000$ & $\$ 15000$ \\
\hline Salary and other Current Costs & $(\$ 1000)$ & $(\$ 1000)$ & $(\$ 3000)$ & $(\$ 3000)$ & $(\$ 3000)$ \\
\hline Post-Production Capital & & & $(\$ 2000)$ & $(\$ 1000)$ & $(\$ 1000)$ \\
\hline Exploration and Development & $(\$ 2000)$ & $(\$ 4000)$ & & & \\
\hline Pre-Royalty Cash Flow ${ }^{(2)}$ & $(\$ 3000)$ & $(\$ 5000)$ & $\$ 5000$ & $\$ 11000$ & $\$ 11000$ \\
\hline Royalty at $25 \%$ if Loss Refunded* & $(\$ 750)$ & $(\$ 1250)$ & $\$ 1250$ & $\$ 2750$ & $\$ 2750$ \\
\hline Carry-Forward $^{(1)}$ & & $(\$ 3150)$ & $(\$ 8557)$ & $(\$ 3735)$ & \\
\hline Royalty Base with Carry-Forward & $(\$ 3000)$ & $(\$ 8150)$ & $(\$ 3557)$ & $\$ 7265$ & $\$ 11000$ \\
\hline $\begin{array}{l}\text { Royalty with Carry-Forward of } \\
\text { Unused Deductions (25\%) }\end{array}$ & & & & $\$ 1816$ & $\$ 2750$ \\
\hline
\end{tabular}

(1) Carry-forward of unused deductions (losses) is at a five-percent rate.

(2) It is assumed the resource is exhausted at the end of year 5. Capital costs are non-recoverable.

The present value of royalty payments (arrived by discounting at five percent to compare current and future periods of cash flow) can be computed for each case.

If full refunds are provided each year a loss is incurred (the refund equal to the loss multiplied by the royalty rate of 25 percent), the present value of royalty payments is equal to $\$ 3831$, which is exactly 25 percent of pre-royalty cash flows (hence a rent-based royalty).

Under the rent-based royalty without a full refund, any unused deductions are carried forward at a rate of five percent to preserve the full value of the deduction (five percent being the discount rate for comparing future values with the first year). For example, the loss of $\$ 3000$ is carried forward to the next year to be deducted from the royalty base. In addition, $\$ 150$ is provided a deduction equal to five percent multiplied by the loss carryover. The latter amount is often referred to as the investment allowance.

The present value of royalty payments under the carry-forward method is equal to $\$ 3831$ in the above example, exactly equal to the full-refund royalty payment.

12 A similar point is made in the Mirrlees report. See Institute of Fiscal Studies, the Mirrlees Review, Tax By Design, chapter 17, 2011. http://www.ifs.org.uk/mirrleesReview/design. 
It is important to understand that the METRR does not provide an estimate of the overall taxes and royalties governments collect, since those amounts depend on both the marginal and inframarginal returns that projects earn. It is not unusual, for example, for the marginal effective tax rate to be negative even though the government is collecting tax revenues. The implication is that any losses for the marginal investment are being used to offset taxes paid on inframarginal returns, or carried forward to shelter income from royalties in the future. ${ }^{13}$ The METRR is a benchmark with which to determine the effects of taxes and royalties on investment decisions. If loss deductions cannot be fully utilized, the negative values would be reduced (closer to zero).

As noted by others, resource projects are large capital-intensive projects with both fixed and variable capital requirements. The tax system may not only discourage investment at the margin but also the decision to invest at all. One should therefore consider not only the marginal effective tax and royalty rate on capital allocation as we do, but also the overall tax burden on total returns, which is typically used in cash flow project analysis. This point is further discussed in the next section.

The unique aspect of our work is its accounting for the time taken to develop non-renewable resource projects before they are available for extraction. ${ }^{14}$ There are several stages of production, including exploration and development phases to discover reserves and make them available for extraction. With these two stages, the analysis is based on a flow of inputs to develop a reserve available for production of oil and gas - a "time-to-build" analysis. ${ }^{15}$ The following stage of production and extraction depletes the discovered reserves until exhaustion. We do not consider the downstream processing stage in this study.

To derive the METRR for resource companies, we include exploration, development, depreciable capital, and inventories. The analysis is based on calculating the present value of income earned from projects that yield an annualized rate of return on capital. The gross-oftax-and-royalty rate of return on capital is equal to the inflation-adjusted cost of financing

13 Locke, Ibid. Locke is further confused with our analysis by assuming that a project earns a six percent average rate of return equal to the marginal rate of return (so infra-marginal returns are not earned by the project). It is important to keep in mind that businesses invest until the pre-tax rate of return on capital is equal to the tax-adjusted cost of capital (both measured net of risk), so that the average rate of return on capital in aggregate is more than the marginal return. Our focus is on the impact of taxes and royalties on investment decisions (Mintz, $1996 \mathrm{ibid}$.).

14

Our modelling follows that found in Robin Boadway, Neil Bruce, and Jack Mintz, "Taxation, Inflation and the Effective Marginal Tax Rate on Capital in Canada," Canadian Journal of Economics 17 (1,1984): 62-79; Robin Boadway et al., "Marginal Effective Tax Rates for Capital in the Canadian Mining Industry," Canadian Journal of Economics 30 (1, 1987): 1-16; Jeffrey Mackie-Mason and Jack Mintz, "Corporate Taxation and the Building of Capital: Implications for Expensing and Capitalization of Costs," (mimeographed, University of Toronto, 1991); and Kenneth J. McKenzie, Mario Mansour, and Ariane Brûlé, "The Calculation of Marginal Effective Tax Rates," Working Paper 1997-15 (Ottawa: Department of Finance, 1997). For details, see Mintz, "Measuring Effective Tax Rates for Oil and Gas in Canada," The School of Public Policy, SPP Technical Papers, March 2010.

15 The "time-to-build" analysis results in a higher cost of capital for a company, since its income is earned after spending has taken place for a period of time. Tax payments are affected since tax deductions for exploration and development spending are taken prior to income being earned when the resource is exploited. The delay in creating income raises the cost of capital, but the mismatch of income and expenses under the tax system reduces the cost of capital. 
capital (taking into account interest deductibility), adjusted for taxes. The net-of-tax-androyalty rate of return on capital is equal to the weighted average of the interest rate for debt, and the imputed cost of equity finance provided by savers to fund the investment. The tax and royalty the business pays is the difference between the gross-of-tax-and-royalty rate of return on capital and the net-of-tax-and-royalty rate of return on capital. The METRR on capital is equal to the tax and royalty paid divided by the gross-of-tax-and-royalty rate of return on capital.

The analysis includes corporate income taxes, rent-based taxes, royalties and the like (e.g., the state severance tax in the US), capital-related, and sales taxes. We also take into account various features of taxes, such as the valuation of inventories, capital-cost allowances, and the investment tax credit (e.g., the Atlantic Investment Tax Credit, or AITC in Canada).

Appendix A provides a brief derivation of the equations used to estimate METRRs for nonrenewable resources in general.

\section{COMPARISON WITH AVERAGE TAX RATES STUDIES}

The marginal effective tax and royalty rate (METRR) results provide an indication as to how the fiscal regimes would affect the allocation of oil investment. With marginal analysis, there is no need to specify project revenues and costs, since companies will invest in capital until the rate of return on capital is equal to the cost of capital. What we are required to do is to measure the cost of capital with adjustments for taxes and royalties. ${ }^{16}$

There have been other studies that focus on average cash flows earned by the industry, which requires a specification of revenues and costs that are best representative of the industry even though they widely vary by project. Specific companies, in planning their investments, would reasonably use their own revenues and costs based on the geological and other factors that impact on their cash flows. Average effective tax and royalty rates are calculated as a share of the internal rate of return earned on resource investment projects, which are typically above the cost of capital used for marginal analysis.

The average effective tax and royalty rate is quite sensitive to the internal rate of return. For example, with a high internal rate of return, a fiscal regime with a high statutory rate and accelerated cost deductions and tax credits could have an average effective tax and royalty rate greater than the case of a regime with low rates and broad bases. With a low internal rate of return, the opposite could hold if low rates and broad-based tax and royalty systems have a smaller tax impact than high rates and narrow bases, since few rents are earned subject to the adjusted internal rates of return equal to the observed cost of capital at the margin), the average effective tax rate analysis could lead to a conclusion that a high-rate, narrow-base regime imposes a higher tax burden on capital investments than a low-rate, broad-base regime with a high internal rate of return on projects.

\footnotetext{
${ }^{16}$ As described in Appendix A, we first derive the user cost of capital (gross of depreciation and risk in principle), adjusted for royalties and taxes. The return on capital (net of risk) is equal to the user cost of capital net of depreciation and risk.
} 
While it would be useful to understand how the marginal and average analyses compare often making little difference - the data needed for average tax rate analysis are more demanding since risk-adjusted internal rates of return are specific to projects. ${ }^{17}$ Marginal effective tax rate analysis requires a measurement of the cost of capital only since the pre-tax and royalty (net-of-risk) rate of return on capital is equal to it.

\section{THE STATUTORY OIL FISCAL REGIME BY COUNTRY: AN OVERVIEW}

Outside of direct government ownership, a tax/royalty regime that collects revenue from private oil companies may involve three levies: “(1) a royalty to secure a minimum payment, (2) the regular income tax that is applicable to all companies, and (3) a resource rent tax to capture a large share of the profits of the most profitable projects." 18 Among the countries under study, a given tax/royalty regime may consist of different combinations of these three government levies and may involve either both a royalty and a rent tax or only one of them. More interestingly, recent reforms (e.g., those undertaken by Australia, Norway, the UK and Alberta for the oil sands) are converging towards application of a rent-based tax through which the government shares both income risk and reward with the oil industry. In the meantime, while Canada is struggling to strike a balance between encouraging resource investment and collecting an appropriate share of oil rent, unreformed regimes still heavily rely on revenuebased royalties (e.g., Brazil and the US).

Table 1 provides a summary of the statutory fiscal regime by country. Referring to this table, we provide some observations below concerning the 13 regimes existing in six countries.

\footnotetext{
17 Another type of analysis is to evaluate the effect of taxation on lumpy investments - this is the average effective tax and royalty rate on capital by assuming a rate of return on capital in excess of the marginal rate of return (that equals the cost of capital). The average rate of return (or internal rate of return), properly adjusted for risk, is however unknown. We do know that companies will not invest in capital if they cannot cover both risk and the cost of capital.

18 Emil M. Sunley, et al, (2003) “Revenue from the Oil and Gas Sector: Issues and Country Experience,” pp. 153-183 in J.M. Davis, R. Ossowski and A. Fedelino (eds) Fiscal Policy Formulation and Implementation in Oil-Producing Countries (International Monetary Fund: Washington D.C.).
} 


\section{TABLE 1 OIL AND GAS FISCAL STRUCTURE OF MAJOR PRODUCING JURISDICTIONS IN 2012 - A SUMMARY}

\begin{tabular}{|c|c|c|c|c|}
\hline Jurisdiction & Overview & Company income tax & Royalty & Rent-based tax \\
\hline Australia & $\begin{array}{l}\text { Effective } 1 \text { July 2012, } \\
\text { there will be virtually } \\
\text { only two levies: the } \\
\text { general corporate } \\
\text { income tax (CIT) and } \\
\text { the petroleum resource } \\
\text { rent tax (PRRT). All the } \\
\text { existing state and } \\
\text { federal resource taxes } \\
\text { will be creditable } \\
\text { against current and } \\
\text { future PRRT liabilities } \\
\text { and the PRRT is } \\
\text { deductible for CIT } \\
\text { purposes. }\end{array}$ & $\begin{array}{l}\text { The corporate income tax } \\
\text { rate is currently } 30 \\
\text { percent. In addition to } \\
\text { general allowances, } \\
\text { expenditure on exploration } \\
\text { or prospecting activities } \\
\text { and expenditure on } \\
\text { rehabilitating mine sites, } \\
\text { including removal of } \\
\text { redundant offshore } \\
\text { platforms, may be } \\
\text { expensed for petroleum } \\
\text { firms. }\end{array}$ & $\begin{array}{l}\text { Federal and state royalties vary by } \\
\text { region, but they are all creditable } \\
\text { against the petroleum resource rent } \\
\text { tax and hence have virtually no } \\
\text { impact on capital and business } \\
\text { allocation. }\end{array}$ & $\begin{array}{l}\text { AG Petroleum Resource } \\
\text { Rent Tax (PRRT) on } \\
\text { offshore projects: the tax } \\
\text { rate is } 40 \text { percent, under } \\
\text { which the exploration } \\
\text { and rehabilitation } \\
\text { expenditures are } \\
\text { expensed and may be } \\
\text { carried forward on an } \\
\text { uplift rate of } 15 \\
\text { percentage points above } \\
\text { the government long- } \\
\text { term bond rate (LTBR). } \\
\text { Other capital expenditure } \\
\text { may be carried forward } \\
\text { at a rate of five percent } \\
\text { points above LTBR. }\end{array}$ \\
\hline Brazil & $\begin{array}{l}\text { In addition to the } \\
\text { regular corporate } \\
\text { income tax, there are } \\
\text { four main ad valorem } \\
\text { levies: a revenue-based } \\
\text { royalty, a landowner fee, } \\
\text { a progressive "special } \\
\text { participation" (SP) } \\
\text { charge, and a } \\
\text { mandatory investment } \\
\text { in R\&D when there is } \\
\text { an SP charge payable. } \\
\text { There are also two } \\
\text { fixed-amount levies: the } \\
\text { rental fees and the } \\
\text { signature bonus. } \\
\text { All the levies targeting } \\
\text { the oil industry except } \\
\text { SP are deductible for } \\
\text { SP purposes, and all } \\
\text { the oil-specific } \\
\text { payments are } \\
\text { deductible for income } \\
\text { tax purposes. }\end{array}$ & $\begin{array}{l}\text { The combined corporate } \\
\text { income tax rate is } 34 \\
\text { percent including a } 15 \\
\text { percent basic rate, a } 10 \\
\text { percent surtax and a nine } \\
\text { percent social contribution } \\
\text { tax. } \\
\text { Under the corporate } \\
\text { income tax, exploration } \\
\text { costs may be expensed } \\
\text { while the development } \\
\text { and capital expenditures } \\
\text { are depreciated according } \\
\text { to the normal tax } \\
\text { depreciation scheme. }\end{array}$ & $\begin{array}{l}\text { The royalty is } 10 \text { percent on the } \\
\text { value of products sold, net of any } \\
\text { indirect taxes and transportation } \\
\text { costs using common carriers; } \\
\text { The one percent landowner fee, } \\
\text { applicable to onshore activities only, } \\
\text { shares the same base as royalties. } \\
\text { The rental fees are based on the } \\
\text { area of fields and location; the } \\
\text { signature bonus is a lump sum } \\
\text { payment due upon signing the } \\
\text { contract. }\end{array}$ & $\begin{array}{l}\text { A special participation } \\
\text { (SP) fee is levied on } \\
\text { substantial profits (net of } \\
\text { all the other oil and gas } \\
\text { levies) that surpass the } \\
\text { threshold on a field-by- } \\
\text { field basis. The threshold } \\
\text { volume varies by location } \\
\text { (onshore or offshore, the } \\
\text { later is further } \\
\text { differentiated by water } \\
\text { depth) and declines with } \\
\text { the production years } \\
\text { (Year } 1,2,3 \text { and } 4+\text { ). } \\
\text { The SP rate is } \\
\text { progressive from } 10 \\
\text { percent to } 40 \text { percent, } \\
\text { depending on the } \\
\text { aforementioned varying } \\
\text { thresholds. Costs of } \\
\text { exploration, development } \\
\text { and depreciable assets } \\
\text { are treated as under CIT, } \\
\text { but "Brazil equipment" is } \\
\text { allowed a fast write-off. } \\
\text { Financial cost is not } \\
\text { deductible. }\end{array}$ \\
\hline $\begin{array}{l}\text { Canada } \\
\text { - Federal }\end{array}$ & $\begin{array}{l}\text { The federal CIT rate is } \\
15 \text { percent, under } \\
\text { which all provincial } \\
\text { royalty payments are } \\
\text { deductible. The Atlantic } \\
\text { Investment Tax Credit of } \\
10 \text { percent for } \\
\text { qualifying investment } \\
\text { expenditures in } \\
\text { resource and } \\
\text { manufacturing } \\
\text { industries is provided } \\
\text { (being phased out by } \\
\text { 2015). }\end{array}$ & $\begin{array}{l}\text { The special tax provisions } \\
\text { include: a } 100 \text { percent } \\
\text { allowance for exploration } \\
\text { cost, a } 30 \text { percent annual } \\
\text { allowance for development } \\
\text { and a } 25 \text { percent } \\
\text { allowance for a special } \\
\text { class of depreciable } \\
\text { assets (Class } 41 \text { ), } \\
\text { covering a broad range of } \\
\text { assets used by the } \\
\text { resource sector. }\end{array}$ & $\begin{array}{l}\text { The federal government collects } \\
\text { royalties only from oil and gas } \\
\text { produced on the "frontier lands," } \\
\text { including the "territorial sea" and } \\
\text { "continental shelf," which are outside } \\
\text { the scope of this study. }\end{array}$ & None \\
\hline
\end{tabular}




\begin{tabular}{|c|c|c|c|c|}
\hline Jurisdiction & Overview & Company income tax & Royalty & Rent-based tax \\
\hline Alberta & $\begin{array}{l}\text { Royalties are deductible } \\
\text { under the corporate } \\
\text { income tax. }\end{array}$ & $\begin{array}{l}\text { The corporate income tax } \\
\text { rate is } 10 \text { percent and the } \\
\text { tax base matches that of } \\
\text { the federal government. }\end{array}$ & $\begin{array}{l}\text { For conventional oil and gas, the } \\
\text { royalty rate is based on gross } \\
\text { revenue or production and is } \\
\text { sensitive to both the market price } \\
\text { and well productivity. For oil, the } \\
\text { royalty ranges from zero to } 40 \\
\text { percent, and for natural gas five } \\
\text { percent to } 36 \text { percent. There is also } \\
\text { an initial five percent royalty that } \\
\text { applies in the first } 12 \text { months with a } \\
\text { volume cap. } \\
\text { As for oil sands, a progressive gross } \\
\text { royalty ranging from one to nine } \\
\text { percent applies before payout. It is } \\
\text { creditable against the net royalty } \\
\text { (unused credits are carried forward } \\
\text { at the investment allowance rate). }\end{array}$ & $\begin{array}{l}\text { For the oil sands only, in } \\
\text { addition to a pre-payout } \\
\text { gross royalty, there is a } \\
\text { net royalty of } 25 \text { to } 40 \\
\text { percent after payout } \\
\text { depending on the price } \\
\text { level of the oil. }\end{array}$ \\
\hline $\begin{array}{l}\text { British } \\
\text { Columbia }\end{array}$ & $\begin{array}{l}\text { Royalties are deductible } \\
\text { under the corporate } \\
\text { income tax. }\end{array}$ & $\begin{array}{l}\text { The CIT rate is } 10 \text { percent } \\
\text { and the tax base matches } \\
\text { that of the federal } \\
\text { government. }\end{array}$ & $\begin{array}{l}\text { For conventional oil and gas, the } \\
\text { royalty is based on gross revenue. } \\
\text { The royalty rate differs first by } \\
\text { product category, such as density of } \\
\text { oil or type of gas (i.e., conservation } \\
\text { vs. non-conservation gas) and by } \\
\text { well age (except for heavy oil and } \\
\text { conservation gas). Then the } \\
\text { formulation of the royalty rate for a } \\
\text { given product category differs } \\
\text { between oil and gas. For oil, the } \\
\text { royalty rate is sensitive mainly to } \\
\text { productivity; for gas, the royalty is } \\
\text { sensitive only to price. } \\
\text { For certain high-cost shale gas } \\
\text { projects, there is a pre-payout two } \\
\text { percent royalty on gross revenue } \\
\text { (refer to next column). }\end{array}$ & $\begin{array}{l}\text { For certain high-cost } \\
\text { shale gas projects, a } \\
\text { newly introduced net } \\
\text { profit royalty program } \\
\text { with four tiers of royalty } \\
\text { rates applies: a pre- } \\
\text { payout two percent } \\
\text { royalty on gross revenue } \\
\text { and three post-payout } \\
\text { tiers associated with a } \\
\text { royalty that is the greater } \\
\text { of five percent of gross } \\
\text { revenue and a higher } \\
\text { rate of net revenue (i.e., } \\
15 \text { percent, } 20 \text { percent, } \\
\text { or } 35 \text { percent, depending } \\
\text { on the tier order). To } \\
\text { reach each of the three } \\
\text { tiers of net royalty, a } \\
\text { progressive return } \\
\text { allowance applies. }\end{array}$ \\
\hline Saskatchewan & $\begin{array}{l}\text { The crown royalties and } \\
\text { freehold production } \\
\text { taxes are deductible for } \\
\text { CIT purposes. } \\
\text { There is also a resource } \\
\text { surcharge under the } \\
\text { corporate capital tax } \\
\text { regime, which is } \\
\text { deductible for CIT } \\
\text { purposes. }\end{array}$ & $\begin{array}{l}\text { The corporate income tax } \\
\text { rate is } 12 \text { percent and the } \\
\text { tax base matches that of } \\
\text { the federal government. }\end{array}$ & $\begin{array}{l}\text { The crown royalty and the freehold } \\
\text { production tax (FPT) on oil and gas } \\
\text { are determined using formulas } \\
\text { containing parameters that are } \\
\text { adjusted monthly by the government. } \\
\text { Both royalty and FPT are sensitive to } \\
\text { price and well productivity and differ } \\
\text { by product in terms of their vintage } \\
\text { and characteristics (e.g., type of } \\
\text { product, well and location). The FPT } \\
\text { is lower than the crown royalty by a } \\
\text { production tax factor (PTF), which } \\
\text { varies by the type of product and } \\
\text { ranges from } 6.9 \text { to } 12.5 \text { percentage } \\
\text { points. }\end{array}$ & None \\
\hline
\end{tabular}




\begin{tabular}{|c|c|c|c|c|}
\hline Jurisdiction & Overview & Company income tax & Royalty & Rent-based tax \\
\hline NF\&L & $\begin{array}{l}\text { The royalties are } \\
\text { deductible for CIT } \\
\text { purposes. The generic } \\
\text { royalty regime consists } \\
\text { of a basic royalty and a } \\
\text { two-tier net royalty. Note } \\
\text { that unsuccessful } \\
\text { exploration expenditure } \\
\text { is disallowed for the } \\
\text { purpose of calculating } \\
\text { the royalty. }\end{array}$ & $\begin{array}{l}\text { The corporate income tax } \\
\text { rate is } 14 \text { percent and the } \\
\text { tax base matches that of } \\
\text { the federal government. }\end{array}$ & $\begin{array}{l}\text { Under the generic offshore oil royalty } \\
\text { structure: a basic royalty is charged } \\
\text { on gross revenues at rates rising } \\
\text { from one to } 7.5 \text { percent as } \\
\text { cumulative production rises and } \\
\text { before payout of all the project costs } \\
\text { and the basic gross royalty and the } \\
\text { compounded return allowance are } \\
\text { exhausted. } \\
\text { The basic royalty is payable over the } \\
\text { entire production period. But after } \\
\text { the payout, it is first creditable } \\
\text { against the Tier-1 net royalty and } \\
\text { further deductible from the base for } \\
\text { Tier-2 royalty. }\end{array}$ & $\begin{array}{l}\text { A two-tier net royalty ( } 20 \\
\text { percent and } 10 \text { percent), } \\
\text { along with a two-tier } \\
\text { return allowance, applies } \\
\text { after payout. Tier-1 net } \\
\text { royalty applies after all } \\
\text { the project costs and the } \\
\text { basic gross royalty and } \\
\text { the compounded Tier-1 } \\
\text { return allowance are } \\
\text { exhausted. Tier-2 royalty } \\
\text { becomes payable after } \\
\text { the payout of both gross } \\
\text { royalty and Tier-1 net } \\
\text { royalty along with the } \\
\text { Tier-2 return allowance. } \\
\text { The return allowance is } \\
\text { five percentage points } \\
\text { above LTBR for Tier-1 } \\
\text { and } 15 \text { points above } \\
\text { LTBR for Tier-2. }\end{array}$ \\
\hline Nova Scotia & $\begin{array}{l}\text { The royalties are } \\
\text { deductible for CIT } \\
\text { purposes. } \\
\text { The generic offshore } \\
\text { royalty regime consists } \\
\text { of a two-tier gross- } \\
\text { revenue royalty and a } \\
\text { two-tier net royalty } \\
\text { depending on the gross } \\
\text { and net revenue levels } \\
\text { respectively. Note that } \\
\text { unsuccessful } \\
\text { exploration expenditure } \\
\text { is disallowed for the } \\
\text { purpose of calculating } \\
\text { the royalty. }\end{array}$ & $\begin{array}{l}\text { The corporate income tax } \\
\text { rate is } 16 \text { percent and the } \\
\text { tax base matches that of } \\
\text { the federal government. }\end{array}$ & $\begin{array}{l}\text { The revenue-based, or gross royalty } \\
\text { is two-tiered - two percent before } \\
\text { payout and five percent after payout } \\
\text { - and deductible for calculating the } \\
\text { base for the net-revenue royalty. } \\
\text { Note that regardless of the revenue } \\
\text { and profit level being reached, the } \\
\text { two percent gross royalty applies for } \\
\text { a minimum of } 24 \text { months, and the } \\
\text { five percent gross royalty applies for } \\
\text { a minimum of } 36 \text { months. This } \\
\text { implies that there is no net royalty, or } \\
\text { rent tax payable for the first five } \\
\text { years after the commencement of } \\
\text { production. }\end{array}$ & $\begin{array}{l}\text { The two-tier net royalty } \\
\text { rate is } 20 \text { percent and } \\
30 \text { percent, depending } \\
\text { on the net-revenue tier } \\
\text { reached. } \\
\text { Even after the net } \\
\text { royalties become } \\
\text { payable, only the greater } \\
\text { rate of the five percent of } \\
\text { gross revenue and } 20 \\
\text { percent or } 35 \text { percent of } \\
\text { the net revenue is } \\
\text { payable. To reach each of } \\
\text { the two tiers of the net } \\
\text { royalty scheme, a } \\
\text { progressive return } \\
\text { allowance applies: } 20 \\
\text { percentage points above } \\
\text { LTBR for Tier-1 and } 45 \\
\text { points above LTBR for } \\
\text { Tier-2. }\end{array}$ \\
\hline Norway & $\begin{array}{l}\text { The regime consists of } \\
\text { two parts: the ordinary } \\
\text { income tax and a } \\
\text { special tax. The total } \\
\text { marginal tax rate on } \\
\text { profit from offshore oil } \\
\text { production is } 78 \\
\text { percent. }\end{array}$ & $\begin{array}{l}\text { The corporate income rate } \\
\text { is } 28 \text { percent. Exploration } \\
\text { costs are expensed. A } \\
\text { cash refund is provided for } \\
\text { tax losses resulting from } \\
\text { exploration. Oil production } \\
\text { facilities and pipelines } \\
\text { may be depreciated within } \\
\text { six years with a straight- } \\
\text { line rate up to } 162 / 3 \\
\text { percent. }\end{array}$ & None & $\begin{array}{l}\text { The special tax is } 50 \\
\text { percent. The tax base is } \\
\text { the CIT base gross of } \\
\text { financing cost and net of } \\
\text { an uplift (=7.5 percent of } \\
\text { the cost price of } \\
\text { depreciable operating } \\
\text { assets including } \\
\text { development } \\
\text { expenditures for the first } \\
\text { four consecutive years) } \\
\text { and unused uplift carried } \\
\text { forward from previous } \\
\text { years }\end{array}$ \\
\hline
\end{tabular}




\begin{tabular}{|c|c|c|c|c|}
\hline Jurisdiction & Overview & Company income tax & Royalty & Rent-based tax \\
\hline The UK & $\begin{array}{l}\text { The regime as applied } \\
\text { to oil and gas fields } \\
\text { that are given } \\
\text { development consent } \\
\text { on or after } 16 \text { March } \\
1993 \text { consists of a ring- } \\
\text { fence corporation tax } \\
\text { (RFCT) and a } \\
\text { supplementary charge } \\
\text { (SC), with a combined } \\
\text { tax rate of } 62 \text { percent. }\end{array}$ & $\begin{array}{l}\text { The ring-fence corporation } \\
\text { tax is } 30 \text { percent. It differs } \\
\text { from the standard CIT (24 } \\
\text { percent) with some } \\
\text { important modifications: } \\
\text { (1) exploration, appraisal, } \\
\text { development and } \\
\text { installation of production } \\
\text { are all } 100 \text { percent } \\
\text { deductible, (2) there is a } \\
100 \text { percent first-year } \\
\text { allowance for all types of } \\
\text { capital except for the } \\
\text { costs of acquiring mineral } \\
\text { assets, which attracts a } \\
10 \text { percent annual relief, } \\
\text { and (3) a } 10 \text { percent ring } \\
\text { fence expenditure } \\
\text { supplement for up to six } \\
\text { years. }\end{array}$ & $\begin{array}{l}\text { None in relation to fields that are } \\
\text { given development consent on or } \\
\text { after } 16 \text { March } 1993 .\end{array}$ & $\begin{array}{l}\text { A supplementary charge } \\
\text { of } 32 \text { percent on the } \\
\text { RFCT tax base with } \\
\text { finance costs added } \\
\text { back. }\end{array}$ \\
\hline The US & $\begin{array}{l}\text { The main tax is the } \\
\text { federal corporate } \\
\text { income tax. There is } \\
\text { also a federal royalty } \\
\text { payable by oil and gas } \\
\text { producers on federal } \\
\text { properties, which is } \\
\text { deductible for CIT } \\
\text { purposes. }\end{array}$ & $\begin{array}{l}\text { The corporate income tax } \\
\text { rate is } 31.85 \text { percent } \\
\text { since } 2010 \text { for "domestic } \\
\text { productive activities" } \\
\text { including oil and gas } \\
\text { business. The E\&D } \\
\text { expenditure may be either } \\
\text { expensed or depleted } \\
\text { after the commencement } \\
\text { of production. }\end{array}$ & $\begin{array}{l}\text { The royalty arising from the federal } \\
\text { properties is } 1 / 8 \text { of the value of } \\
\text { onshore production and } 1 / 6 \\
\text { offshore. But this royalty is beyond } \\
\text { the focus of our study. }\end{array}$ & None \\
\hline Arkansas & $\begin{array}{l}\text { There are three } \\
\text { principal levies in the } \\
\text { state: the severance } \\
\text { tax, the royalty and the } \\
\text { CIT. The severance tax is } \\
\text { deductible for royalty } \\
\text { purposes, and both } \\
\text { severance tax and } \\
\text { royalty payments are } \\
\text { deductible for income } \\
\text { tax purposes. }\end{array}$ & $\begin{array}{l}\text { The corporate income tax } \\
\text { rate is progressive with the } \\
\text { top rate being } 6.5 \text { percent } \\
\text { on net taxable income } \\
\text { exceeding } \$ 100,000 \text {. }\end{array}$ & $\begin{array}{l}\text { The general severance tax is five } \\
\text { percent with a reduced rate of } 1.5 \\
\text { percent available to new discovery } \\
\text { gas (for the first two years) and high- } \\
\text { cost gas (for the first three years). } \\
\text { The statutory royalty rate is } 1 / 8 \text { but } \\
\text { a higher royalty rate is possible. }\end{array}$ & None \\
\hline Colorado & $\begin{array}{l}\text { The principal levies are } \\
\text { the income tax and the } \\
\text { severance tax. The } \\
\text { royalty appears to be a } \\
\text { local levy that may be } \\
\text { partially creditable } \\
\text { against the severance } \\
\text { tax. }\end{array}$ & $\begin{array}{l}\text { The CIT rate is } 4.63 \\
\text { percent. }\end{array}$ & $\begin{array}{l}\text { The severance tax is five percent for } \\
\text { oil and gas, four percent for oil shale } \\
\text { but with reduced rates (i.e., one, two } \\
\text { and three percent respectively) for } \\
\text { the first three years of production. }\end{array}$ & None \\
\hline
\end{tabular}




\begin{tabular}{|c|c|c|c|c|}
\hline Jurisdiction & Overview & Company income tax & Royalty & Rent-based tax \\
\hline Pennsylvania & $\begin{array}{l}\text { There are three } \\
\text { principal state levies: } \\
\text { income tax, capital } \\
\text { stock tax and loan tax. } \\
\text { Debate is still ongoing } \\
\text { about whether the state } \\
\text { should have a } \\
\text { severance tax on } \\
\text { resources. }\end{array}$ & $\begin{array}{l}\text { The CIT rate is } 9.9 \\
\text { percent, the capital stock } \\
\text { tax rate is } 0.289 \text { percent, } \\
\text { but will be eliminated by } \\
2014 \text {, and the loan tax } \\
\text { rate is } 0.4 \text { percent. }\end{array}$ & None & None \\
\hline Texas & $\begin{array}{l}\text { There are three levies } \\
\text { on state-owned } \\
\text { resource properties: a } \\
\text { royalty, a severance tax } \\
\text { (or oil and gas } \\
\text { production taxes) and a } \\
\text { franchise tax. The royalty } \\
\text { is deductible in } \\
\text { calculation of the } \\
\text { severance tax, and both } \\
\text { payments are } \\
\text { deductible for the } \\
\text { purposes of the state } \\
\text { franchise tax. }\end{array}$ & $\begin{array}{l}\text { The Franchise Tax is one } \\
\text { percent based on the } \\
\text { taxable margin, which is } \\
\text { the least of the following } \\
\text { three calculations: total } \\
\text { revenue minus cost of } \\
\text { goods sold, total revenue } \\
\text { minus compensation, or } \\
\text { total revenue times } 70 \\
\text { percent. }\end{array}$ & $\begin{array}{l}\text { The royalty rate is within the range of } \\
16.67 \text { percent and } 25 \text { percent. } \\
\text { The severance tax or production tax } \\
\text { is based on the total production at } \\
\text { market value. The rate is } 4.6 \text { percent } \\
\text { for crude oil and } 7.5 \text { percent for } \\
\text { natural gas. }\end{array}$ & None \\
\hline
\end{tabular}

* Our compilation is based on various government websites listed below:
Australia
http://www.futuretax.gov.au/content/Content.aspx?doc=FactSheets/resource_tax_regime.htm
Brazil
http://www.anp.gov.br/brasil-rounds/round4/round4/workshop/restrito/ingles/PartGov-R4I.pdf and http://www.anp.gov.br/brasil-rounds/round1/Docs/LD0C02_en.pdf

\section{Canada}
For Western Canada http://www.energy.gov.ab.ca/Tenure/pdfs/FISREG.pdf
For NF\&L
NF\&L royalty regulation: http://assembly.nl.ca/Legislation/sr/regulations/rc030071.htm\#30
For Nova Scotia http://www.gov.ns.ca/energy/resources/ra/offshore/offshore-petroleum-royalty-regime.pdf
Norway
http://www.regjeringen.no/en/dep/fin/Selected-topics/taxes-and-duties/bedriftsbeskatning/ Taxation-of-petroleum-activities.html?id=417318
United Kingdom http://www.hmrc.gov.uk/international/ns-fiscal3.htm\#f and http://www.hmrc.gov.uk/manuals/otmanual/index.htm

\section{United States}
For treating E\&D http://www.taxalmanac.org/index.php/Internal_Revenue_Code:Sec._167._Depreciation
For depreciable assets http://books.google.com/ then search: Patrick A. Hennessee, "Oil and Gas: Federal Income Taxation"
For state income taxes CCH US Master Multistate Corporate Tax Guide
Arkansas http://www.aogc.state.ar.us/
Colorado http://www.colorado.gov/cs/Satellite/Revenue/REVX/1176842266433 and http://www.michie.com/colorado/Ipext.dll?f=templates\&fn=main-h.htm\&cp=
Pennsylvania $\quad$ http://www.portal.state.pa.us/portal/server.pt/community/corporation_taxes/11420
Texas http://www.window.state.tx.us/taxinfo/taxpubs/index.html\#mineral 


\section{Canada}

In Canada, the oil and gas fiscal regime is comprised of two parts: an income tax system that is applied to the oil and gas industry along with other industries but with special features earmarked only to the oil and gas industry, and a provincial royalty system that varies significantly from province to province. ${ }^{19}$ Some of these royalty systems include a rent-based tax in the name of net royalty (see below).

By focusing on the general settings of provincial royalty regimes, there appear to be two approaches to such regimes in Canada.

The first is well established in the three Western provinces where the conventional oil and gas industry is developed on a well-by-well basis. This approach generally sets a royalty rate based on gross revenue for every specified product, and such a royalty rate is often sensitive to market price and well size.

The second approach follows the rent tax or "cash flow" taxation as recently discussed in the Australian Henry Report. ${ }^{20}$ It emerged along with the offshore drilling that developed in the early 1990s in Nova Scotia and Newfoundland \& Labrador. This approach was later used by Alberta (oil sands) and British Columbia (shale gas) - although each province used its own distinct framework.

In the case of Atlantic offshore oil and gas, the royalty system is designed to consist of multitiered net-profit royalty rates along with staged payout definitions and progressive allowances for rates of return. Also, unlike the treatment under corporate income taxes, the unsuccessful exploration costs are generally disallowed for royalty purposes. The difference between the systems in Nova Scotia and Newfoundland \& Labrador lies in the degree of complexity. In Nova Scotia, at each tier, only one royalty rate is virtually accountable for the net royalty payable and the return allowance is applied without compounding. In contrast, the Newfoundland \& Labrador system requires more complicated calculations for the ultimate royalty payments: a cumbersome offsetting mechanism between the basic royalty and the twotier net royalties and the return allowance with compounding. Note that, compared to the extremely generous return allowance provided under the Nova Scotia royalty regime (e.g., 20 and 45 percentage points, respectively, above the government long-term bond rate used in calculating the Tier-1 and Tier-2 net royalty payment), the Newfoundland \& Labrador system appears to be much less excessive (i.e., five and 15 points above LTBR respectively) in this regard.

For the oil sands in Alberta, the royalty is based on net revenue after payout and is set to be price-sensitive, but has no other complexities. Cost deductions are carried forward at the government bond interest rate as an investment allowance, following the cash flow royalty model discussed above. In the case of shale gas in $\mathrm{BC}$, an extremely complex net royalty regime was recently introduced largely following the royalty model of Nova Scotia.

\footnotetext{
19 Canada also has an incentive for flow-through shares where the federal government and many provinces provide a personal income tax credit for equity owners to invest in junior oil, gas and mining companies. We do not include flow-through shares in this analysis as we focus on large companies only.

${ }^{20}$ Commonwealth of Australia (2010): Australia's Future Tax System, Report to the Treasurer, December.
} 
The corporate income tax in Canada applies the general statutory rate to profits, which is a combined federal-provincial rate (varying from 25 percent in Alberta and British Columbia to 31 percent in Nova Scotia). Resource companies deduct from corporate taxable income 100 percent of exploration expenditures, 30 percent of development expenditures (on a declining basis), capital cost allowances for post-production investment expenditures, provincial royalties, labour and inventory costs. ${ }^{21}$

\section{The United States}

The four states covered in our study are Arkansas, Colorado, Pennsylvania and Texas. With no attempt to implement tax reform of any kind over the past several decades, there is no rentbased tax in any of these four states.

For oil production involving state ownership, there are two principal revenue-based levies: a state royalty and a state severance tax. Both the royalty and severance taxes are based on the gross revenue net of transportation cost, and neither of them is sensitive to oil prices. ${ }^{22}$ Although the royalty and severance taxes are deductible for federal and state income tax purposes, the mechanism through which royalty and severance tax partially offset one another differs among the states. For example, in Arkansas, the severance tax is deductible for royalty purposes while in Texas it is the reverse. Pennsylvania is an outlier since it has not yet targeted the oil industry specifically for revenue, but has imposed a couple of capital-based taxes in general.

Under the federal and state corporate income tax legislation, the general amortization period for exploration and development expenditure incurred by any "major integrated oil company" is seven years (refer to the US Internal Revenue Code, Sec. 167(h) ${ }^{23}$ ). And according to $\mathrm{CCH},{ }^{24}$ most of the depreciable assets used for oil and gas production fall in the five-year property class with the US MACRS system. The federal corporate income tax rate in the United States is 35 percent, with a reduced rate of 31.85 percent applied to domestic producers including those in the oil industry, and state corporate income taxes are deductible from the federal tax.

\section{Australia, Brazil, Norway and the UK}

These four countries are grouped together only because their fiscal regimes all include a profitor rent-based tax in addition to company income taxes. But the similarity stops here with Brazil presenting the most burdensome and complex system, while the other three countries generally introduced a rent-based tax.

\footnotetext{
21 The 2012 Federal Budget phases out the Atlantic Investment Tax Credit of 10 percent for oil, gas and mining companies by 2015 .

22 The severance tax may be reduced for certain newly discovered wells or high-cost wells. But we apply only the general severance tax rate in our model.

23 Online source: http://www.taxalmanac.org/index.php/Internal_Revenue_Code:Sec._167._Depreciation

24 See Patrick A. Hennessee, "Oil and gas: federal income taxation," CCH, 2008, page 551-552. http://books.google.com
} 
Effective from 1 July 2012, the Australian regime includes only the general corporate income tax (CIT) and the petroleum resource rent tax (PRRT) that is deductible from corporate taxable income. The state royalties that currently target only oil and gas production are to be creditable against PRRT. Under the PRRT, all expenditures are immediately expensed and a range of uplift allowances is applicable against unutilized losses and capital write-offs: 15 percentage points above the Australian Government long-term bond rate (LTBR) for exploration and five percentage points above the LTBR for other expenditures. The corporate income tax regime is similarly structured to that of Canada, with exploration being expensed and development expenditures written off similar to the treatment of depreciable assets. The corporate income tax rate is 30 percent (which is to be reduced by one point to 29 percent in 2013-14).

The Brazilian regime consists of multi-layered company income taxes and numerous levies on oil and gas projects, either at ad valorem rates or by a fixed amount. The corporate income tax provisions include a combined tax rate of 34 percent, a relatively tight annual allowance for depreciable assets and full expensing for exploration costs. The ad valorem levies targeting oil and gas projects include principally a 10 percent royalty based on the gross revenue, a one percent landowner fee sharing the royalty base, but on onshore production only, and a progressive "special participation" (SP) charge of up to 40 percent of the net income. This special participation charge is applied to a tax base similar to the corporate income tax base in terms of allowances for various capital expenditures, but includes a complicated scheme consisting of multiple brackets for taxable volume that vary by type of production, location of field and years of production. Financing costs are disallowed for SP purposes.

All the non-corporate income tax levies except SP are deductible for SP purposes, and all the non-corporate income tax levies including SP are deductible for corporate income tax purposes.

The profit-based petroleum taxes in Norway and the UK differ from that of Australia and Brazil in that they are an add-on tax, rather than being deductible from corporate taxable income. Accordingly, the tax is called a "special tax" in Norway and a "supplementary charge" in the UK. While the financing cost under the additional tax is disallowed, a 7.5 percent uplift factor (up to four years) is provided in Norway to carry forward unused depreciation deductions including development expenditures. In the UK, the special tax and the ring-fence corporation tax virtually share the same base as the corporate income tax except for the non-deductibility of interest costs: all capital expenditures except that for acquiring resource assets may be fully written off in the year in which they are incurred, and a 10 percent ring-fence expenditure supplement for up to six years is provided for carrying forward losses associated with exploration and development costs.

\section{THE METRR ANALYSIS}

By calculating the METRR, we attempt to answer the following comparative questions:

- First, how much do corporate income taxes and royalties impact on oil and gas investment decisions at the margin across countries?

- Second, how do the different fiscal levies interact with each other in different ways among different fiscal regimes?

- And finally, which regime fares better overall on the scale of optimization? 
For descriptive convenience, we present the METRR in three groups: (1) Canada by province, (2) the US by state, and (3) the other four countries. We compare the METRRs with marginal effective tax rates of non-resource industries within each of the 13 jurisdictions to determine the extent to which the oil industry is comparably taxed or not taxed at the margin. After providing a base-case analysis, we will disentangle the METRR impact between the effects of the fiscal levies specifically targeting the oil industry, and the general corporate income taxes and other taxes affecting capital investment.

Several technical assumptions are made in our METRR calculations and the corresponding parameters are provided in Appendix B. Since oil production differs tremendously across countries, types of product (e.g., offshore vs. onshore) and areas of production, these assumptions are made only to set a baseline for comparative purposes; they can be adjusted for tailored policy designs in individual countries. For example, it is assumed in our model that, according to the distribution of expenditures, the average time required for exploration and before the commencement of production is five years, while that for development is one year (these are times that are based on the distribution of expenditures according to Canadian data). In reality, it might have taken up to 10 years or more to discover an offshore field and more than five years to develop an oil sands production site. By adjusting this assumption to fit actual parameters, the METRR results will change and hence indicate whether there is a need for any specific policy simulations.

For Canada, in responding to the sensitivity to well production and oil price within the three Western royalty regimes, the METRRs are calculated based on a daily production of oil of 80 barrels and at an average price level of US\$76 per barrel (this is calculated by taking a fiveyear average of West Intermediate Texas prices, which are discounted relative to international prices). While the assumption of a daily production is irrelevant to jurisdictions other than the three Western provinces for conventional oil, the assumption of a price level is important to convert the revenue-based royalty rate to the profit-based rate that is used in our METRR model for jurisdictions that impose revenue-based royalties (i.e., Brazil, Canada and the US). Otherwise, this assumption is irrelevant to jurisdictions where oil-specific levies are rent-based and insensitive to oil prices.

In the case of the oil sands royalty, the rent-based royalty rate varies with prices between $\$ 55$ per barrel (with a royalty rate of 25 percent) to $\$ 120$ per barrel (with a royalty rate of 40 percent). In principle, the differential royalty rates could influence the overall METRR if the royalty rate that is applied to costs differs from the royalty rate applied to future resource rents earned from the marginal investment decision. As we have discussed elsewhere, ${ }^{25}$ the METRR is underestimated if the future royalty rate (due to high prices) is higher than the current royalty rate and vice versa. In our calculations below, we assume that the royalty rate is unchanging over time - even though this is unlikely to be the case.

Also, given the complexity of the royalty regimes in the two Atlantic provinces, we provide METRR calculations only for the case when the second-tier incremental (net) royalty is payable in Newfoundland \& Labrador, and when the first-tier net royalty is payable in Nova Scotia. This type of assumption is irrelevant to other jurisdictions for METRR calculations.

25 J. Mintz and D. Chen, "Taxing Canada's Cash Cow: Tax and Royalty Burdens on the Oil and Gas Industry," SPP Briefing Paper, Vol. 3(3), The School of Public Policy, University of Calgary, 2010. 


\section{The Base Case}

Table 2 provides effective tax and royalty rates for the oil industry by country and by type of assets. This calculation is fully based on current tax and royalty provisions as laid out in Table 1 and hence is designated as the "base case.".

We begin with an analysis of the effective tax rate on the resource sector as a whole by asset class (Table 2). Table 3 provides further data for analyzing the base case METRR numbers provided in Table 2. This second set of reference data consists of a comparison between the resource and non-resource marginal effective tax (and royalty) rates. It also includes data on statutory tax and royalty rates on gross oil income, taking into account the specific offsetting mechanism between these taxes and royalties. For example, in Norway and the UK, this combined tax rate is 78 percent and 62 percent respectively, as their rent taxes are direct addons to the corporate income tax rate. In contrast, Brazil's combined tax/royalty rate ranges from 47 percent to 64 percent as the revenue-based royalty (10 percent) is deductible in calculating the profit-based royalty (ranging from 10 percent to 40 percent), and all the royalty payments are deductible for income tax purposes.

Several observations may be drawn from base-case calculations as shown below in Table 2 (with reference to Table 3):

TABLE 2 MARGINAL EFFECTIVE TAX AND ROYALTY RATES FOR OIL INDUSTRY BY JURISDICTION (IN PERCENT), 2012, INCLUDING ALL TAXES AND ROYALTIES

\begin{tabular}{|l|r|c|c|c|c|}
\hline & Exploration & Development & Depreciable & Inventory & Aggregate \\
\hline Canada* & & & & & \\
BC & 27.7 & 32.5 & 29.5 & 23.2 & 30.0 \\
Alberta & & & & & \\
$\quad$ Conventional & 48.4 & 51.8 & 21.9 & 23.2 & 40.3 \\
$\quad$ Oil sands & -2.9 & 5.6 & 33.0 & 33.1 & 27.7 \\
Saskatchewan & 36.7 & 41.2 & 33.7 & 26.4 & 37.1 \\
N\&L & 6.4 & -3.3 & 67.5 & 32.1 & 12.9 \\
Nova Scotia & -6.9 & -16.5 & 34.5 & 32.1 & 0.9 \\
\hline The US & & & & & \\
Arkansas & 24.0 & 26.6 & 35.2 & 26.2 & 28.8 \\
Colorado & 28.6 & 30.9 & 33.2 & 25.2 & 30.9 \\
Pennsylvania & 4.2 & 7.7 & 38.3 & 28.2 & 17.5 \\
Texas & 31.7 & 33.8 & 32.1 & 23.1 & 32.4 \\
\hline Australia & -133.2 & 12.9 & 28.9 & 38.2 & -20.1 \\
Brazil & 48.2 & 49.6 & 74.0 & 45.5 & 57.6 \\
Norway & -3.3 & 14.6 & 63.7 & 82.9 & 28.2 \\
The UK & -4.1 & -0.8 & 3.8 & 71.1 & 4.6 \\
\hline
\end{tabular}

* Assumes that the retail sales tax in BC is restored and the Atlantic Investment Tax Credit for oil and gas activities is fully phased out as proposed in the 2012 Federal Budget in Canada.

${ }^{26}$ As mentioned earlier, Table E2 in Appendix E also provides some critical non-tax parameters. 
First, by glancing only at the aggregated METRR, Brazil applies the highest tax and royalty burden on oil industry with a METRR of 58 percent. ${ }^{27}$ This is substantially higher than the marginal effective tax rate on capital in its non-resource industries (32 percent) in Table 3 ).

Brazil is distantly followed by Alberta (40 percent for conventional oil) and Saskatchewan (37 percent). In both cases, non-resource investments at the margin are subject to less taxation (18 percent in Alberta and 25 percent in Saskatchewan as in Table 3).

On the other end of the scale, Australian oil and gas investments are subject to the least taxation at the margin (-20 percent), followed by Nova Scotia ( 0.9 percent), the UK (five percent) and Newfoundland \& Labrador (13 percent). In these cases, except for Newfoundland \& Labrador, oil and gas investments at the margin are subject to much less taxation than nonresource investments.

Those jurisdictions in the middle ground are Texas (32 percent), Colorado (31 percent), British Columbia (30 percent), Arkansas (29 percent), Norway (28 percent), Alberta (28 percent for the oil sands) and Pennsylvania (18 percent). We note that oil sands investments bear a higher marginal effective tax and royalty rate than the marginal effective tax rate in non-resource sectors (this is a result of interactions between corporate income tax and the rent-based royalty as discussed in Appendix A). This is very similar to the situation in Norway. In the United States, oil investments at the margin face a lower tax burden compared to non-resource industries. (Note that we do not include temporary depreciation allowances in the marginal effective tax rate calculations.)

27 This is resulted from the highest net royalty rate of 40 percent, the same rate as that of the rent tax in Australia. By applying its lowest net royalty rate of 10 percent, the METRR for Brazil's oil industry would be 38 percent, which is still above its METR for the non-resource sector. 


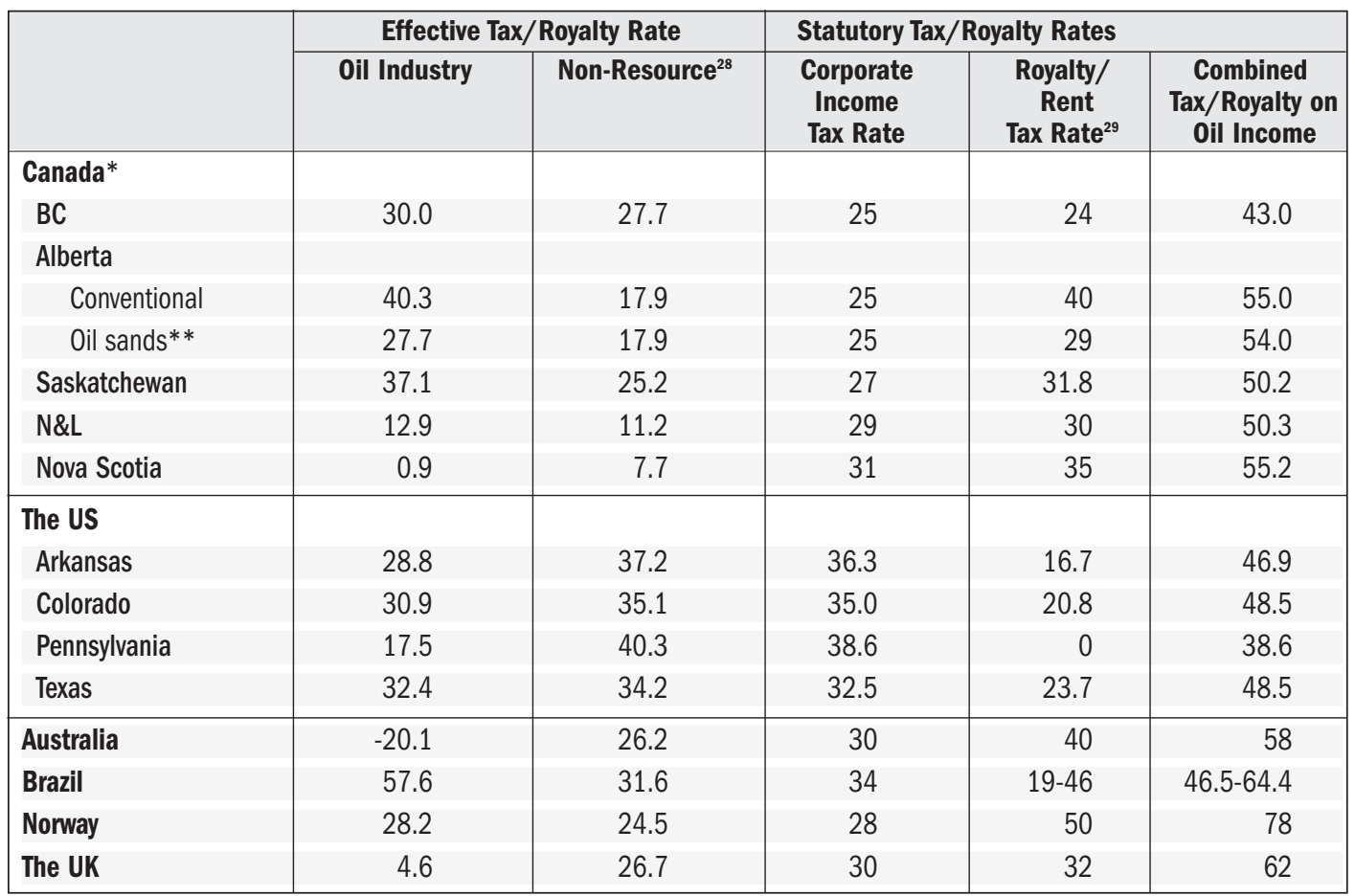

* Assumes that the retail sales tax in $B C$ is restored and the Atlantic Investment Tax Credit is fully phased out.

** Excluding the fast write-off for mining assets that is still partially available to oil sands but will be completely phased out for oil sands by 2015.

Second, among the lowest-taxed regimes, different factors contribute to the negative METRR to various degrees:

- For Australia, the excessive uplift for exploration expenditure, which is 15 percentage points above the long-term government bond rate (LTBR), is the main contributor to the overall negative METRR. That is, with the current LTBR at 3.9 percent, an uplift of 18.9 percent for exploration results in a METRR on exploration below a negative rate of 133 percent. Given the exploration share of 27 percent in total capital investment in the oil industry, the overall METRR for Australia is -20 percent. By reducing the uplift factor for exploration from 18.9 percent to 8.9 percent, the latter rate being applicable to development and other depreciable assets, the METRR for exploration would be about two percent and the overall METRR of 16 percent, which is a level still well below that for non-resource sectors in Australia (26 percent).

${ }^{28}$ Chen and J. Mintz, "2012 Annual Global Tax Competitiveness Ranking - A Canadian Good News Story,” SPP Research Papers, 5 (28) September 2012. Note that temporary tax preferences such as tax holidays and bonus depreciation are excluded in these calculations.

29 The complexity of provincial royalty regimes in Canada requires the following explanatory notes: for BC, the royalty rate is for a third-tier oil with conventional oil well production above $159 \mathrm{~m} 3 / \mathrm{month}$, for Alberta, the rate is for daily production of $80 \mathrm{bbs} /$ day at a price of $\$ 76 / \mathrm{bbl}$, for Saskatchewan, the rate includes the 30.1 percent royalty and the 1.7 percent corporation capital tax resource surcharge, for Newfoundland \& Labrador, we assume that Tier- 2 has been reached and both Tier-1 and Tier-2 net royalties are payable, and for Nova Scotia, the rate shown is the Tier-2 net royalty rate. For the US, the royalty rate shown in the table is the combined rate of the severance tax and royalty, taking into account the specific partial offsetting mechanism by state. For Brazil, the combined royalty rates contain only the 10 percent revenue-based royalty and the profit-based royalty rate ranging from 10 percent to 40 percent, with the former deductible in calculating the latter. 
- In Nova Scotia, the provincial return allowance (Tier-1) - 20 percentage points above the LTBR - contributes another reduction to the METRR of over 10 percentage points. In other words, by reducing the return allowance to the LTBR, the METRR in Nova Scotia would be 11 percent, which is about three percentage points higher than that for the nonresource sector in the province. By allowing unsuccessful exploration expenditures, the METRR would be about four percent. On the other hand, the METRR for the non-resource sector would be substantially higher (i.e., 23 percent) should the AITC and the provincial ITC be also eliminated for the qualified business within the non-resource sector.

- In the UK, the tax regime treats all capital assets except inventories with expensing. This provision helps reduce the gap in METRR between exploration (normally the least taxed) and depreciable assets (normally the highest taxed) down to eight percentage points. With the newly increased ring-fence expenditure supplement of 10 percent (up from the previous six percent), the application of tax losses associated with exploration and development expenditures to other income and matching the prescribed rate for carry-forward of allowance with the risk-inclusive industry discount rate, the resulting METRR for the oil industry is substantially lower than that for the non-resource sector.

In Newfoundland \& Labrador (N\&L), the METRR is about 13 percent, about 2 percentage points higher than that for its non-resources industries as a whole. This indicates the absence of a fiscal preference for oil investments in the province unlike the case of Nova Scotia. Similar to Nova Scotia, N\&L provides multi-layer royalty rates and return allowances and disallows any unsuccessful exploration costs (i.e., dry holes) for royalty purpose. But the return allowance in N\&L is not as substantial as that provided in Nova Scotia. Moreover, the tiered net royalties in N\&L are incremental rather than mutually offsetting, as in the case of NS. By allowing unsuccessful exploration costs to be deducted from the royalty base, the METRR for the oil industry would be one percentage point below that for non-resource sectors in the province. In the meantime, the fiscal subsidy associated with the return allowance in N\&L is still substantial and sufficient to match the tax preference associated with the AITC provided to the qualified non-resource sectors. ${ }^{30}$

Third, among the three regimes with high taxes on investments at the margin, each has distinctive issues.

- For Brazil, the comparatively high company income tax rate (34 percent) and less generous tax allowance for depreciable assets, most of which depreciate faster in economic terms than the tax provisions allow, are general contributors to its high METRR for both the oil industry and the non-resource sectors. Furthermore, Brazil collects both a revenue-based royalty of 10 percent and a profit-based royalty of up to 40 percent, which are applied in our model, and the former is only allowed to reduce the base for the latter rather than offset the latter. Finally, Brazil's relatively high inflation rate (five percent) has also contributed to its higher METRR. Should its inflation rate be reduced to Norway's level of two percent, its METRR for the oil and gas industry could drop by seven points to 51 percent.

30 That is, by reducing the return allowance to the LTBR and excluding AITC for non-resource industries, the METRR for the oil industry and the METR for non-resource industries as a whole would be both around 20 percent in N\&L. 
- The METRR for conventional oil in Alberta is also high despite the fact that the province cut the top royalty rate from 50 percent to 40 percent in 2010 . This is because this revenuebased top rate (40 percent) applies at a moderate price level for wells with moderate productivity (e.g., at $\$ 70 / \mathrm{bbl}$ for well productivity of 80 barrels per day). As a result, after crossing the threshold price of $\$ 70 / \mathrm{bbl}$, for a given well productivity (e.g., 80 barrels per day), the METRR appears to be higher at a moderate price level $(\$ 76 / \mathrm{bbl})$ than at possible higher price levels, say over $\$ 100 / b b l$.

- In Saskatchewan, a unique tax factor is the 1.7 percent resource surcharge, which accounts for three percentage points of its overall METRR. Other tax factors contributing to the rather high METRR include the provincial retail sales tax, which adds to the cost of capital good purchases, the relatively high provincial corporate income rate (12 percent percent vs. 10 percent in Alberta and $\mathrm{BC}$ ) and a relatively high royalty rate (i.e., over 30 percent at a modest price of $\$ 76 / \mathrm{bbl}$ compared to 24 percent in $\mathrm{BC}$, which is insensitive to oil prices).

And finally, on the middle ground occupied by British Columbia, Alberta (oil sands), the four states in the US and Norway, a common feature is the relative evenness in the METRR across different types of assets (except for Alberta, Norway and Pennsylvania).

- In the four states in the US, viewing all taxes and royalties combined, Texas appears to be the highest-taxed state, followed by Colorado, Arkansas and Pennsylvania. Our subsequent simulation will show that their revenue-based royalty and severance taxes place a big portion of the tax burden on the oil industry in these states, except for Pennsylvania where there is no levy specifically targeting the oil industry. ${ }^{31}$ On the other hand, because these levies are based on gross revenue and are insensitive to price, their impact on capital investment tends to decrease when the oil price rises.

- The regime in British Columbia for conventional oil is similar to those in the states in terms of having a revenue-based royalty that is insensitive to oil prices. Therefore, for a given well productivity, the METRR tends to be higher when the oil price drops.

- In Norway, the 28 percent METRR for its oil industry is slightly higher than that for its non-resource sector. This is so despite the 50 percent special tax for the oil industry on top of the regular 28 percent corporate income tax rate that applies to all industries. Two principal provisions help offset the impact of the seemingly extremely high special tax. One is the cash refund provided for the loss associated with exploration expenditure. And the other is the 7.5 percent uplift for depreciating capital investment including development expenditures.

- The Alberta regime for oil sands is a rent-based royalty that provides a full deduction for capital and current costs from the royalty base. Since the regime provides a return allowance for possible tax losses associated with exploration and development, the METRRs for exploration and development capital are substantially lower than those on other assets.

\footnotetext{
31 This situation may not last long as there has been a heated debate about whether to introduce a resource-based tax so as to generate revenue for the state. According to the Wall Street Journal (October 4, 2011, online edition), Pennsylvania Governor Tom Corbett has proposed a controversial fixed natural-gas drilling fee of $\$ 160,000$ per well.
} 
Table 2 also illustrates that exploration and development expenditures tend to be more favourably treated than other asset expenditures in the oil and gas industry, except in those jurisdictions that rely on revenue-based royalties (particularly, Alberta for conventional oil, British Columbia, Saskatchewan and most US states). Where more preferential treatment is given, especially for development expenditures, incentives are created to shift capital expenditure from post-production to the pre-production stage to take advantage of greater tax savings available under various tax regimes. From the point of view of economic efficiency, it would be better that a more even distribution of tax burdens fall across assets. However, as discussed above, the more favourable treatment for exploration could be viewed as appropriate since such expenditures are related to discovery spillovers, similar to research expenditures that are provided with significant tax benefits, especially in Canada.

As a final point in this section, we note that the combined statutory corporate income and royalty rates on gross income vary sharply among the jurisdictions (Table 3 ). The highest rate is in Norway (78 percent), followed by the UK (62 percent) and the lowest is Pennsylvania (38.6 percent). Many of the combined tax and royalty statutory rates are well above the corporate income tax statutory tax rates for non-resource sectors. These observations raise two important tax policy issues.

The first is that resource investments that earn large rents (high internal rates of return on capital) would pay relatively large tax and royalty payments even if the marginal effective tax and royalty payments were low. Thus, the Norwegian and UK systems, for example, may discourage private producers if they can earn similar pre-tax rents elsewhere.

The second is that very high tax and royalty rates can distort business decisions. They encourage companies to charge lower transfer prices for their sales to reduce the amount of tax and royalty paid to host governments. High marginal rates could also discourage risky investments to the extent that governments do not provide full refundability when losses are incurred. We particularly note that the royalty regimes in both Newfoundland \& Labrador and Nova Scotia have a rather poor feature in that respect - unsuccessful exploration costs are not deductible, but the combined corporate income tax and royalty rates (under the first and second tiers) is above 50 percent. It would be far better to let unsuccessful exploration costs be deducted (with a carry-forward at a riskless interest rate) as part of a simpler structure with a flat net royalty rate.

\section{Decomposing the impact of taxes and royalties}

Table 4 provides further simulations to decompose the effective tax and royalty rate to its individual tax and royalty sources. Column (A) shows the aggregated marginal effective tax and royalty rate taken from Table 2. Column (B) differs from Column (A) by excluding all the fiscal levies targeting only the oil industry, which include royalties, severance taxes (in the US), rent taxes and the special resource charge (in Saskatchewan). Column (C) further excludes from Column B other taxes such as sales taxes on capital purchases (in British Columbia, Saskatchewan and the four states in the US) and the capital-based taxes (in Pennsylvania); that is, Column (C) presents the impact of only corporate income taxes. As a comparison, Column (D) presents METRR attributable only to the fiscal levies targeting the oil industry. Column (E) provides METRR on non-resource sectors as presented in Table 3. 
TABLE 4 DECOMPOSING THE EFFECTIVE TAX AND ROYALTY RATES (IN PERCENT), 2012

\begin{tabular}{|c|c|c|c|c|c|}
\hline & $\begin{array}{l}\text { Incl. } \\
\text { All Fiscal } \\
\text { Levies } \\
\text { (A) }\end{array}$ & $\begin{array}{l}\text { Excl. } \\
\text { Oil Levies } \\
\text { (B) }\end{array}$ & $\begin{array}{l}\text { CIT Only* } \\
\text { (C) }\end{array}$ & $\begin{array}{l}\text { Incl. } \\
\text { Only } \\
\text { Oil Levies } \\
\text { (D) }\end{array}$ & $\begin{array}{c}\text { Reference: } \\
\text { METRR for } \\
\text { non-resource } \\
\text { (E) }\end{array}$ \\
\hline \multicolumn{6}{|l|}{ Canada } \\
\hline British Columbia & 30.0 & 11.1 & 8.6 & 19.1 & 27.7 \\
\hline \multicolumn{6}{|l|}{ Alberta } \\
\hline Conventional & 40.3 & 8.6 & 8.6 & 32.1 & 17.9 \\
\hline Oil sands & 27.7 & 19.4 & 19.4 & 0.0 & 17.9 \\
\hline Saskatchewan & 37.1 & 10.4 & 9.3 & 28.7 & 25.2 \\
\hline N\&L & 12.9 & 8.6 & 8.6 & 7.1 & 11.2 \\
\hline Nova Scotia & 0.9 & 4.1 & 4.1 & -4.8 & 7.7 \\
\hline \multicolumn{6}{|l|}{ The US } \\
\hline Arkansas & 28.8 & 16.0 & 13.2 & 13.5 & 37.2 \\
\hline Colorado & 30.9 & 15.2 & 12.6 & 16.7 & 35.1 \\
\hline Pennsylvania & 17.5 & 17.5 & 14.3 & 0.0 & 40.3 \\
\hline Texas & 32.4 & 14.4 & 11.5 & 19.0 & 34.2 \\
\hline Australia & -20.1 & 19.1 & 19.1 & -58.5 & 26.2 \\
\hline Brazil & 57.6 & 23.7 & 23.7 & 46.7 & 31.6 \\
\hline Norway & 28.2 & 6.3 & 6.3 & 16.5 & 24.5 \\
\hline The UK & 4.6 & -6.5 & -6.5 & 4.4 & 26.7 \\
\hline
\end{tabular}

* Excludes oil levies and other taxes.

There are four observations that may be drawn from Table 4.

First, excluding all the fiscal levies targeting only the oil industry (Column B) such as royalties, rent taxes and other oil levies (e.g., the severance tax and the resource surcharge), the oil industry is taxed lower in all jurisdictions, except for the oil sands in Alberta, compared to the non-resource sector as a whole (Column E). This is mainly attributable to the more favourable treatment of exploration and development expenditures, which account for a far greater share of investment expenditures in the oil industry (over 64 percent), compared to research and development expenditures in the non-resource sector (below five percent). ${ }^{32}$ While preferential treatment of exploration and development compared to other asset expenditures results in less neutral corporate tax, it is comparable to tax support given to research and development. Both preferences are supported for the reasons given above companies would not otherwise fully appropriate the return on their discovery investments. This is especially the case for research and exploration. However, the tax support given for development for both resource and non-resource companies undertaking exploration or research is more questionable in terms of its normative basis.

For the oil sands, the combined capital share in favourably treated exploration and development is much smaller (18 percent vs. 64 percent for conventional and offshore oil investment). Furthermore, depreciable assets used for the oil sands, which account for 80 percent of oil-sands capital, are taxed much higher than their counterparts used for nonresource sectors. ${ }^{33}$

\footnotetext{
32 As noted above, the federal Atlantic Investment Tax Credit also provides support to investments in agriculture, fishing, forestry, mining, oil and gas and manufacturing industries. However, the AITC provides no benefit to service and construction sectors in the Atlantic. The AITC is being phased out for mining, oil and gas investments.

33 This is because the combined depreciation allowance for depreciable assets used for oil sands roughly matches its economic depreciation rate. In contrast, the combined depreciation allowance for depreciable assets used for nonresource sectors are much higher than their economic depreciation rate.
} 
Second, in Australia and Nova Scotia, the METRR, including all fiscal levies (Column A), is lower than that excluding oil levies (Column B). This indicates that their royalty regimes actually provide further tax relief to the oil industry, in addition to the aforementioned favourable treatment under the corporation income tax. This further tax preference is a direct result of the excessive return allowances provided in these two jurisdictions under the oil levies: the 15 percentage points above LTBR in Australia and 20 points or more in Nova Scotia.

Third, other taxes such as the conventional sales tax and capital-based tax (in Pennsylvania only) increase the tax burden by about three percentage points in most jurisdictions where such taxes exist (i.e., BC, Saskatchewan and the four states in the US). But such taxes affect the cost of capital in the non-resource sector as well.

Finally, an important issue is whether oil investments are taxed less lightly at the margin compared to other industries. To the extent that fossil fuel subsidies exist, capital will be allocated to oil investments rather than to other investments in the non-resource sector of that jurisdiction. Our analysis suggests a mixed answer to that question. At present, oil investments are more heavily taxed under tax and royalty regimes than non-resource sectors in Alberta, British Columbia, Saskatchewan and Newfoundland \& Labrador to a less degree, as well as Brazil and Norway. In other cases, oil investments are more favourably taxed, resulting in more capital being allocated to these industries compared to a more neutral system.

\section{CONCLUSION}

The above METRR analysis illustrates that a clean rent-based tax is the most efficient tax in that it imposes no tax burden at the margin. By clean, we mean that all the costs incurred by the oil producer would be expensed or carried over at a return allowance matching a riskless financing cost, with offsets provided to avoid interactions with the corporate income tax. Overall, the Alberta royalty tax base used for the oil sands is the closest to the rent-based royalty regime. By excluding its price sensitivity, the Alberta royalty regime can be a rent-tax model for other countries to follow.

With respect to the corporate income tax, we are of the view that it could be made more neutral by scaling back some tax preferences. While expensing of exploration costs is desirable to compensate for informational spillovers, some questions arise for preferential treatment given for the development costs of discovery investments. 


\section{APPENDIX A ${ }^{a}$}

\section{INTERACTION OF CASH FLOW ROYALTY WITH CORPORATE INCOME TAX: BASIC MODEL FOR NON-RENEWABLE RESOURCES ${ }^{34}$}

A resource firm maximizes the present value of cash flows from its project, subject to the constraint that the extracted resources are equal to the amounts discovered over time. Let $\mathrm{T}$ be the period in which reserves have been discovered and prepared for extraction that begins at that time.

(1) $\quad \operatorname{Max} V=\sum_{O}{ }^{\infty}(1+\mathrm{R})^{-\mathrm{t}} \mathrm{CF}_{\mathrm{t}} \mathrm{dt}$

(2) subject to $\sum_{\mathrm{T}}^{\infty} \mathrm{Q}_{\mathrm{t}} \mathrm{dt}=\mathrm{X}=\sum_{0}{ }^{\mathrm{T}} \mathrm{f}\left[\mathrm{e}_{\mathrm{t}}\right]$ (accumulated reserves equals total extraction)

with $\mathrm{CF}_{\mathrm{t}}=\mathrm{P}_{\mathrm{t}} \mathrm{Q}_{\mathrm{t}} \mathrm{C}\left(\mathrm{Q}_{\mathrm{t}}, \mathrm{K}_{\mathrm{t}}\right)(1+\pi)^{\mathrm{t}}-\left(\delta \mathrm{K}_{\mathrm{t}}+\mathrm{k}_{\mathrm{t}}\right)(1+\pi)^{\mathrm{t}}-\mathrm{TAX}_{\mathrm{c}[\mathrm{t}]}-\mathrm{TAX}_{\mathrm{R}[\mathrm{t}]}$ for $\mathrm{t} \geq \mathrm{T}$ $\mathrm{CF}_{\mathrm{t}}=-\mathrm{e}_{\mathrm{t}}(1+\pi)^{\mathrm{t}}-\mathrm{T}_{\mathrm{c}[\mathrm{t}]}$ for $\mathrm{t} \leq \mathrm{T}$

$\mathrm{V}$ is the present value of the firm's nominal cash flows CF, discounted by the nominal financing rate $\mathrm{R}$ over the lifetime of the firm's project. The nominal cost of finance is the weighted average of debt and equity finance $(\mathrm{R}=\mathrm{Bi}(1-\mathrm{u})+(1-\mathrm{B}) \mathrm{Q})$ used by the firm for all of its projects, adjusted for the deductibility of interest expense.

$\mathrm{C}\left(\mathrm{Q}_{\mathrm{t}}, \mathrm{K}_{\mathrm{t}}\right)$ are current costs that are strictly joint convex in output

$\mathrm{Q}$ (denoted as $\mathrm{C}_{\mathrm{Q}}>0$ and $\mathrm{C}_{\mathrm{QQ}}>0$ ) and capital that reduces costs (denoted as $\mathrm{C}_{\mathrm{K}}<0$ and $\mathrm{C}_{\mathrm{KK}}<0$ ).

$\mathrm{K}_{\mathrm{t}} \quad=$ depreciable capital stock

$\mathrm{k}_{\mathrm{t}} \quad=$ new investment $=\mathrm{K}_{\mathrm{t}+1}-\mathrm{K}_{\mathrm{t}}$

$\delta \quad=$ economic depreciation

$\mathrm{f}\left[\mathrm{e}_{\mathrm{t}}\right] \quad=$ reserves found through spending on exploration in period $\mathrm{t}$ with the function being strictly concave in expenditure on exploration and development (f'>0 and f' $<0$ )

$\mathrm{TAX}_{\mathrm{c}[\mathrm{t}]}=$ corporate tax payments (paid in each period and can be negative)

$\mathrm{TAX}_{\mathrm{R}[\mathrm{t}]}=$ royalty payments in each period $\mathrm{t}$ (only paid after extraction begins)

$\mathrm{P}_{\mathrm{t}} \quad=$ nominal price of output normalized to one and rises at the same inflation rate as other prices $\left(\mathrm{P}_{\mathrm{t}}=\mathrm{P}_{\mathrm{O}}(1+\pi)^{\mathrm{t}}\right.$

34 A similar version to this is published in K. MacKenzie and J. Mintz, "The Myths and Facts of Fossil Fuel Subsidies: A Critique of Existing Studies," SPP Research Paper, 4(14), The School of Public Policy, University of Calgary, 2011. 
The analysis below incorporates corporate income taxes and royalty payments based on revenues and cash flows. Corporate tax is imposed on the revenues earned from the sale of resources net of the costs of production, which include current extraction costs, capital costs allowances and exploration and development costs (exploration is expensed but development is capitalized and written off at the declining balance rate $\sigma$ ). This implies the following:

(3) $\quad \mathrm{TAX}_{\mathrm{c}[\mathrm{t}]}=\mathrm{u}\left\{\mathrm{P}_{\mathrm{t}} \mathrm{Q}_{\mathrm{t}}-\mathrm{C}\left(\mathrm{Q}_{\mathrm{t}}, \mathrm{K}_{\mathrm{t}}\right)(1+\pi)^{\mathrm{t}}-\alpha \mathrm{D}_{\mathrm{t}}-\sigma \mathrm{E}_{\mathrm{t}}(1+\pi)^{\mathrm{t}}-\mathrm{T}_{\mathrm{R}[\mathrm{t}]}\right\}$

(4) $\mathrm{D}_{\mathrm{t}}=\left(\delta \mathrm{K}_{\mathrm{s}}+\mathrm{k}_{\mathrm{s}}\right)(1+\pi)^{\mathrm{t}}-\alpha \mathrm{D}_{\mathrm{t}-1}$

(5) $\quad \mathrm{E}_{\mathrm{t}}=\mathrm{e}_{\mathrm{t}}(1+\pi)^{\mathrm{t}}-\sigma \mathrm{E}_{\mathrm{t}-1}$

(6) with $\alpha=$ capital cost allowance rate, $D_{\mathrm{s}}=$ the undepreciated capital cost base and $\mathrm{E}_{\mathrm{s}}=$ the undepreciated "stock" of exploration and development spending at time $\mathrm{s}$.

Manipulating the terms associated with capital cost allowances and investment, $\left(\delta \mathrm{K}_{\mathrm{t}}+\mathrm{k}_{\mathrm{t}}\right)(1+\pi)^{\mathrm{t}}$, in equation (1) with the insertion of terms in (3), (4) and (5), one can show that the investment costs are reduced by the present value of capital allowances so that:

$$
\begin{aligned}
& \mathrm{CF}_{\mathrm{t}}=\left\{\mathrm{P}_{0} \mathrm{Q}_{\mathrm{t}}-\mathrm{C}\left(\mathrm{Q}_{\mathrm{t}}, \mathrm{K}_{\mathrm{t}}\right)\right\}(1-\mathrm{u})(1+\pi)^{\mathrm{t}}-\left(\delta \mathrm{K}_{\mathrm{t}}+\mathrm{k}_{\mathrm{t}}\right)(1-\mathrm{uZ})(1+\pi)^{\mathrm{t}}-\mathrm{TAX}_{\mathrm{R}[\mathrm{t}]}(1-\mathrm{u}) \\
& \text { for } \mathrm{t} \geq \mathrm{T} \\
& \mathrm{CF}_{\mathrm{t}}=-\mathrm{e}_{\mathrm{t}}\left(1-\mathrm{uZ} \mathrm{Z}^{\prime}\right)(1+\pi)^{\mathrm{t}}-\mathrm{TAX}_{\mathrm{R}[\mathrm{t}]}(1-\mathrm{u}) \text { for } \mathrm{t}<\mathrm{T} \\
& \text { with } \mathrm{Z}=\alpha /(\alpha+\mathrm{R}) \text { and } \mathrm{Z}^{\prime}=\sigma /(\sigma+\mathrm{R})^{35}
\end{aligned}
$$

Note that royalty payments in the exploration and development phase are negative if such costs are deductible from the royalty base, which will be the case for the rent tax.

\section{Revenue-Based Royalty}

Revenue-based royalties are a percentage of the value of extracted output, and the corporate income tax system allows companies to deduct exploration and development expenses against other income earned. Let $\tau$ be the ad valorem payment on sales, $P Q$, so that $T_{R}=\tau P Q$ (suppressing time scripts here on in unless needed). Maximizing equation (1), subject to (2) and (2'), choosing Q, K, k, and E, yields the following:

\section{OUTPUT DECISION}

The choice of Q yields the following result ( $\lambda$ is the Lagrange multiplier for the constraint in (2)):

$$
\begin{aligned}
& (1+r)^{-t}\left(P(1-\tau)-C_{Q}\right)(1-u)=\lambda^{36} \\
& \text { with } r=R-\pi=B i(1-u)+(1-B) Q-\pi
\end{aligned}
$$

\footnotetext{
35 For an explicit derivation, see Jack Mintz, "Corporate Tax Holidays and Investment," World Bank Economic Review, Vol 4, No. 2, 81-102, 1990.

36 The implied Hotelling Rule - the capital gain in holding the asset in the ground is equal to the real net-of-corporate tax cost of finance - is derived by using the first-order conditions from equation (8) for two time periods: $\left[\left(\mathrm{p}_{\mathrm{t}+1^{-}}-\mathrm{p}_{\mathrm{t}}\right)(1-\tau)-\left(\mathrm{C}_{\mathrm{Q}, \mathrm{t}+1^{-}} \mathrm{C}_{\mathrm{Q}, \mathrm{t}}\right)\right] /\left\{\mathrm{p}_{\mathrm{t}}(1-\tau)-\mathrm{C}_{\mathrm{Q}, \mathrm{t}}\right\}=\mathrm{r}$.
} 
The shadow price of extracted output is equal to the marginal value of extracting a marginal unit of output. The royalty rate on ad valorem sales generally reduces quasi-rents and the incentive to extract, since the royalty reduces revenues relative to costs of extraction. On the other hand, the deductibility of interest expense from taxable income lowers the cost of finance and, therefore, increases extraction to early periods.

\section{DEPRECIABLE CAPITAL}

The choice of capital stock and new investment, post-exploration and development, as well as the undepreciated capital cost base and changes to it, yields the following cost of capital for depreciable capital:

$$
-\mathrm{C}_{\mathrm{K}}=(\delta+\mathrm{R}-\pi)(1-\mathrm{uZ}) /(1-\mathrm{u})
$$

This is the familiar cost of capital expression, noting that $\mathrm{R}$ is the weighted average of the cost of debt and equity finance and $\mathrm{Z}$ is the present value of depreciation.

\section{EXPLORATION AND DEVELOPMENT}

The choice of exploration and development, e, yields the following for the cost of capital:



The quasi-rent earned by investing in exploration $\left(\mathrm{P}_{\mathrm{T}}-\mathrm{C}_{\mathrm{Q}_{\mathrm{T}} \mathrm{T}}\right) \mathrm{f}_{\mathrm{t}}$, is equal to the interest-inclusive cost of exploration (the price of exploration and development is set equal to unity) divided by the one minus the royalty imposed on the cost of capital. The term in the denominator $\tau \mathrm{P} /\left(\mathrm{P}-\mathrm{C}^{\prime}\right)$ is the ad valorem tax paid as a share of the quasi-rents on incremental sales (this is expected to be less than one so long as the ad valorem tax rate is less than the margin $\left.\left(\mathrm{P}-\mathrm{C}^{\prime}\right) / \mathrm{P}\right)$. The cost of exploration is reduced by interest deductions taken early at time $\mathrm{t}$ relative to the earning of income at time T. Given the deductibility of interest expense from income, the effect of corporate taxation is to reduce the real cost of finance (r) and the discount factor $(1+r)^{(T-t)}$ resulting in a lower cost of capital (and lower effective tax rate on capital).

\section{Rent-Based Royalty on Cash Flows}

Cash flow is equal to the revenues net of both current and capital costs incurred in undertaking the project. Interest expense is not deductible and unused deductions, fully written off in later years, are carried forward at the riskless bond rate (the uplift factor).

The royalty payment after payout is the following:

$$
T_{R}=\tau\left[P_{t} Q_{t}-C\left(Q_{t}, K_{t}\right)(1+\pi)^{t}-\left(\delta K_{t}+k_{t}\right)(1+\pi)^{t}-e_{t}(1+\pi)^{t}\right]
$$


Which is substituted into equation (3). The determination of output, Q, accords with the following Euler equation:

(10) $(1+\mathrm{r})^{-\mathrm{t}}(1-\tau)\left(\mathrm{P}-\mathrm{C}_{\mathrm{Q}}\right)(1-\mathrm{u})=\lambda$

\section{DEPRECIABLE CAPITAL}

The user cost for depreciable capital for the oil sands case is similar to equation (9), but royalties directly affect the cost of capital because current costs are deductible from the royalty base. That is, changes in the stock of capital reduce current costs, which are netted from royalty payments.

(11) $\left.-\mathrm{C}_{\mathrm{K}}=(\delta+\mathrm{R}-\tau)\{1-\tau(1-\mathrm{u})-\mathrm{uZ})\right\} /[(1-\mathrm{u})(1-\tau)]$

\section{EXPLORATION AND DEVELOPMENT}

The user cost for exploration and development for the cash flow tax is the following:

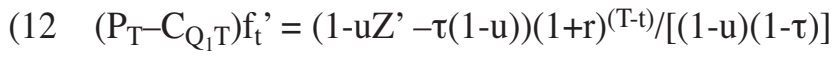

If the corporate tax terms are zero $(\mathrm{u}=0$ and $\mathrm{Z}=1)$, the royalty terms appearing in equations (12) to (14) disappear. Otherwise, the royalty is not neutral as it increases the corporate tax burden on capital. 


\section{APPENDIX B}

\section{TAX AND NON-TAX PARAMETERS FOR THE METRR MODEL}

This appendix provides tax and non-tax parameters for the variables used in our model for calculating marginal effective tax and royalty rates (METRR) by country (see Appendices C-E). We first present a list of these variables with their definitions, and then provide tax parameters in Table B1 and non-tax parameters in Table B2.

\section{List of Variables in the METRR Model:}

$r \quad=\quad$ real financing cost $=\mathrm{R}-\pi$, with

$\mathrm{R}=$ nominal financing cost $=\beta_{\mathrm{i}}\left(1-\mathrm{U}_{\mathrm{c}}\right)+(1-\beta)$ where

$\mathrm{i}=$ nominal interest rate,

$\beta=$ debt-to-assets ratio,

$\mathrm{U}_{\mathrm{c}}=$ regular CIT rate, and

$\varrho=$ cost of equity $=\mathrm{i}(1-\mathrm{m}) /(1-\mathrm{c})$, with

$\mathrm{m}=$ the G-7 average personal income tax (PIT) rate on interest income

$\mathrm{c}=$ the G-7 average PIT rate on equity income $=$ weighted average of PIT rate on dividends and that on capital gains assuming a 40 percent distribution

$\mathrm{R}_{\mathrm{g}}=$ gross-of-tax return to capital

$\mathrm{T}-\mathrm{t}=$ time to build $=$ five years for exploration and one year for development, where $\mathrm{T}$ is the point of the commencement of production

$\mathrm{T}^{\prime}-\mathrm{T}=$ average number of years from commencement of production to payout

$=$ five years, where $T^{\prime}$ is the point of payout, hence $T^{\prime}-t=T^{\prime}-T+T-t=$ total number years from the year of investment to year of payout

$\mathrm{u} \quad=$ the sum of $\mathrm{U}_{\mathrm{c}}$ and $\mathrm{U}_{\mathrm{s}}$

$\mathrm{U}_{\mathrm{c}}=$ the corporate income tax (CIT) rate

$\mathrm{U}_{\mathrm{s}}=$ the supplementary tax that shares the CIT base in general (for Norway and the UK)

$Z^{\prime} \quad=\quad$ the present value of allowances for exploration or development

$\mathrm{Z}=$ the present value of capital cost deductions for depreciable capital: $Z^{\prime}=\alpha /(\alpha+R)$ for declining-base methods and $Z=(1+R) \alpha / R\left[(1+R)^{1 / \alpha}-1\right] /(1+R)^{1 / \alpha}$ for straight-line methods, with $\alpha=$ depreciation allowance

$\psi_{\mathrm{u}}=$ the uplifting factor under both $\mathrm{u}_{\mathrm{c}}$ and $\mathrm{u}_{\mathrm{s}}$ (for the UK only)

$\psi_{\mathrm{s}}=$ the present value of the four-year uplifting factor under $\mathrm{u}_{\mathrm{s}}$ (for Norway only) 
$\tau=$ profit based royalty (Brazil) or rent tax (Australia and the UK)

$Z_{\tau}^{\prime}=$ the present value of allowances for exploration or development under the profitbased royalty (Brazil) or rent tax (Australia and the $\mathrm{UK}$ ), $\mathrm{Z}_{\tau}=1$ for exploration in Brazil and for both exploration and development in Australia and the UK

$\psi_{\tau}=$ the uplifting factor under the rent tax (Australia only)

$\mathrm{g} \quad=$ revenue-based royalty that is deductible for profit-based royalty (Brazil only)

$\left(\mathrm{P}-\mathrm{C}^{\prime}\right) / \mathrm{P}=$ rent to gross income ratio

\section{TABLE B1 TAX PARAMETERS BY COUNTRY, 2012}

\begin{tabular}{|c|c|c|c|c|c|}
\hline CANADA & BC & Alberta & Saskatchewan & N\&L & N.S. \\
\hline$U_{c}=U_{f}+U_{p}$ with $U_{f}=15 \%$ & $25 \%$ & $25 \%$ & $27 \%$ & $29 \%$ & $31 \%$ \\
\hline$U_{S}$ & None & None & None & None & None \\
\hline g & Varying & Varying & Varying & Progressive & 2-tier \\
\hline$T$ & Varying* & Varying** & None & Varying & 2-tier \\
\hline \multicolumn{6}{|c|}{ No uplift or return allowance for income taxes } \\
\hline$\Psi_{\mathrm{T}}$ for Exploration & Varying* & $\mathrm{LTBR}^{* *}$ & NA & 2-tier & 2-tier \\
\hline$\Psi_{\mathrm{T}}$ for Development & Varying* & LTBR** & NA & 2-tier & 2-tier \\
\hline$\Psi_{T}$ for Depreciable & Varying* & $\mathrm{LTBR}^{* *}$ & NA & 2-tier & 2-tier \\
\hline
\end{tabular}

* For shale oil only. $\quad$ ** For oil sands only.

\begin{tabular}{|l|c|c|c|c|}
\hline The US & Arkansas & Colorado & Pennsylvania & Texas \\
\hline $\mathrm{U}_{\mathrm{C}}=\mathrm{U}_{\mathrm{f}}\left(1-\mathrm{U}_{\mathrm{S}}\right)+\mathrm{U}_{\mathrm{S}}$ with $\mathrm{U}_{\mathrm{f}}=31.85 \%$ & $36.3 \%$ & $35.0 \%$ & $38.6 \%$ & $32.5 \%$ \\
$\mathrm{U}_{\mathrm{S}}=$ state $\mathrm{CIT}$ rate & $6.5 \%$ & $4.63 \%$ & $9.9 \%$ & $1.0 \%$ \\
$\mathrm{~g}^{*}$ & $17 \%$ & $21 \%$ & None & $24 \%$ \\
$\mathrm{~T}$ & None & None & None & None \\
No uplifting allowance of any kind & & & & \\
\hline
\end{tabular}

* This is a combined rate for both severance tax and royalty taking into account the partial offsetting mechanism between the two.

\begin{tabular}{|c|c|c|c|c|}
\hline The Other Four & Australia & Brazil & Norway & The UK \\
\hline$u=U c+U s$ & $30 \%$ & $34 \%$ & $78 \%$ & $62 \%$ \\
\hline Uc & $30 \%$ & $34 \%$ & $28 \%$ & $30 \%$ \\
\hline Us & None & None & $50 \%$ & $32 \%$ \\
\hline g & None & $11 \%$ & None & None \\
\hline$T$ & $40 \%$ & Varying & None & None \\
\hline$\Psi_{u}$ for Exploration & None & None & See Table 1 & $10 \%$ \\
\hline$\Psi_{u}$ for Development & None & None & See $\psi_{\mathrm{s}}$ & $10 \%$ \\
\hline$\Psi_{u}$ for Depreciable & None & None & See $\psi_{s}$ & None \\
\hline$\Psi_{\mathrm{S}}$ for Exploration & NA & NA & See Table 1 & $10 \%$ \\
\hline$\Psi_{\mathrm{s}}$ for Development & NA & NA & $7.5 \%, 4$ years & $10 \%$ \\
\hline$\Psi_{\mathrm{s}}$ for Depreciable & NA & NA & $7.5 \%, 4$ years & None \\
\hline$\Psi_{\mathrm{T}}$ for Exploration & LTBR+15\% & None & NA & NA \\
\hline$\Psi_{\mathrm{T}}$ for Development & $\mathrm{LTBR}+5 \%$ & None & NA & NA \\
\hline$\Psi_{\mathrm{T}}$ for Depreciable & LTBR+5\% & None & NA & NA \\
\hline
\end{tabular}


TABLE B2 NON-TAX PARAMETERS BY COUNTRY, 2012



* $\quad$ Our estimate based on CPI for 2005-11, published by the World Bank up to 2010 and The Economist for 2011.

** Adopted from our Canadian model and applied across borders.

$\star * *$ It is the sum of the country-specific inflation rate and the cross-border real interest rate.

$\star \star \star \star$ Based on The Economist, Jan 21st, 2012, Economic and Financial Indicators. 


\section{APPENDIX C}

\section{THE CANADIAN OIL METRR MODEL}

This appendix presents key equations for estimating the marginal effective tax and royalty rate (METRR) for the oil industry in Canada. Table 1 in the text provides a summary of the oil fiscal regime by province. Appendix B provides a list of definitions and two tables of specific parameters (Tables B1 and B2) for the variables that appear in the METRR equations below.

The five provinces covered in our model are British Columbia (BC), Alberta (AB), Saskatchewan (SAS), Nova Scotia (NS) and Newfoundland \& Labrador (N\&L).

The general oil and gas fiscal regime in Canada is comprised of two parts: an income tax system that taxes the oil and gas industry along with other industries under the same umbrella, but with earmarked features that are applicable only to the oil and gas industry, and a provincial royalty system that varies significantly from province to province.

Due to the diversity and complexity among the provincial oil royalty regimes, there is no generic model that applies to Canada as a whole. We therefore present the METRR model for calculating the gross-of-tax rate of return, or $\mathrm{R}_{\mathrm{g}}$, below, province by province. The equations are numbered in the order of their presentation.

The basic assumption for our calculation of METRR in Canada is: the daily production of oil is 80 barrels and the oil price is $\$ 76 / \mathrm{bbl}$. This assumption does not apply in the case of offshore drilling. The assumed price level does determine the royalty rate applied to our calculation of METRR for the oil sands.

Note that in most cases, we provide an identical equation for exploration and development (E\&D), but this does not mean that exploration (CEE, or Canadian exploration expenditure) and development (CDE) incur the same METRR. The fact that CEE and CDE are treated differently under the income taxes - CEE is expensed and CDE is allowed a 30 percent writeoff annually - determine that they incur very different METRRs.

\section{ALBERTA}

Alberta collects royalty from its conventional oil and gas sector based on gross revenue, and that from its oil sands based on net revenue after the payout point. The royalty rate ranges from 15 to 40 percent for conventional oil and from 25 to 40 percent for the post-payout oil sands project.

FOR CONVENTIONAL OIL AND GAS:

For depreciable assets:

(1) $\mathrm{R}_{\mathrm{g}}=(\delta+\mathrm{R}-\pi)(1-\mathrm{uZ}) /(1-\mathrm{u})-\delta$

For inventory:

(2) $\quad \mathrm{R}_{\mathrm{g}}=(\mathrm{R}-\pi(1-\mathrm{u})) /(1-\mathrm{u})$ 
For E\&D:

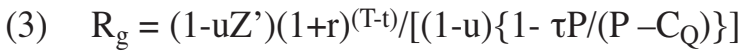

\section{FOR OIL SANDS:}

For depreciable assets:

(4) $\left.\mathrm{R}_{\mathrm{g}}=(\delta+\mathrm{R}-\tau)\{1-\tau(1-\mathrm{u})-\mathrm{uZ})\right\} /[(1-\mathrm{u})(1-\tau)]-\delta$

For inventory:

(5) $\mathrm{R}_{\mathrm{g}}=((\mathrm{R}-\pi)(1-\tau(1-\mathrm{u}))+\mathrm{u} \pi) /[(1-\mathrm{u})(1-\tau)]$.

For E\&D:

(6) $\quad \mathrm{R}_{\mathrm{g}}=\left(1-\mathrm{u} \mathrm{Z}^{\prime}-\tau(1-\mathrm{u})\right)(1+\mathrm{r})^{(\mathrm{T}-\mathrm{t}) /[(1-\mathrm{u})(1-\tau)]}$

\section{BRITISH COLUMBIA}

For conventional products, the royalty rate applies to the gross revenue. The formulation of royalty differs between oil and gas. For oil, the royalty is sensitive to both the age and production by well; for gas, the royalty is sensitive only to the price level.

For depreciable assets:

(7) $\quad \mathrm{R}_{\mathrm{g}}=(\delta+\mathrm{R}-\pi)(1-\mathrm{uZ})(1+x) /(1-\mathrm{u})-\delta$, with $x=$ effective PST rate

For inventory:

(8) $\quad \mathrm{R}_{\mathrm{g}}=(\mathrm{R}-\pi(1-\mathrm{u})) /(1-\mathrm{u})$

For E\&D:

(9) $\quad \mathrm{R}_{\mathrm{g}}=(1-\mathrm{uZ})(1+\mathrm{r})^{(\mathrm{T}-\mathrm{t})} /\left[(1-\mathrm{u})\left\{1-\tau \mathrm{P} /\left(\mathrm{P}-\mathrm{C}_{\mathrm{Q}}\right)\right\}\right]$

\section{SASKATCHEWAN}

The tax and royalty regime in Saskatchewan is similar to that in BC for conventional oil and gas. The only addition is a 1.7 percent resource surcharge applicable to the sales value of oil and gas.

For depreciable assets:

(10) $\mathrm{R}_{\mathrm{g}}=(\delta+\mathrm{R}-\pi)(1-\mathrm{uZ})(1+\chi) /[(1-\mathrm{u})(1-\mathrm{s})]-\delta$, with $\mathrm{s}=$ the resource surcharge

For inventory:

(11) $\mathrm{R}_{\mathrm{g}}=[\mathrm{R}-\pi(1-\mathrm{u})] /[(1-\mathrm{u})(1-\mathrm{s})]$

For E\&D:

(12) $\mathrm{R}_{\mathrm{g}}=(1-\mathrm{uZ})(1+\mathrm{r})^{(\mathrm{T}-\mathrm{t})} /\left[(1-\mathrm{u})\left(1-\tau \mathrm{P} /\left(\mathrm{P}-\mathrm{C}_{\mathrm{Q}}\right)\right)(1-\mathrm{s})\right]$ 


\section{NOVA SCOTIA}

For NS, we assume "if Tier-1 is only reached" when the royalty payable is the greater of five percent of gross revenue and 20 percent of net revenue (refer to NS "royalty regulation").

For depreciable assets:

(13) $\mathrm{R}_{\mathrm{g}}=(\delta+\mathrm{R}-\pi)\left\{(1-\mathrm{uZ})-\tau_{1}(1-\mathrm{u})\right\} /\left[(1-\mathrm{u})\left(1-\tau_{1}\right)\right]-\delta$

For inventory:

(14) $\mathrm{R}_{\mathrm{g}}=\left[(\mathrm{R}-\pi)\left(1-\tau_{1}\right)+\pi \mathrm{u}\right] /\left[(1-\mathrm{u})\left(1-\tau_{1}\right)\right]$

For exploration:

(15) $\mathrm{R}_{\mathrm{g}}=(1+\mathrm{r})^{\mathrm{T}}\left\{1-\mathrm{uZ}-\omega \tau_{1}(1-\mathrm{u})\left(1+\psi_{1}-\mathrm{R}\right)^{\left.\mathrm{T}_{1}-\mathrm{t}\right)}\right\} /\left[(1-\mathrm{u})\left(1-\tau_{1}\right)\right]$

with $\omega=$ the ratio of successful CEE allowed for royalty purpose $=60$ percent.

For development:

$$
\left.R_{g}=(1+r)^{T}\left\{1-u Z^{\prime}-\tau 1(1-u)\left(1+\psi_{1}-R\right)^{T 1-t}\right)\right\} /\left[(1-u)\left(1-\tau_{1}\right)\right]
$$

\section{NEWFOUNDLAND AND LABRADOR}

Newfoundland and Labrador presents one of the most complicated royalty regimes in Canada. It is similar to the net royalty regime in Nova Scotia in terms of its multi-tier royalty rates along with layered return allowances and disallowing the unsuccessful exploration expenditures. The main differences between the N\&L royalty regime and that of NS are the following: (1) after the simple payout, the multi-tier royalties in N\&L are payable in an additive manner (albeit with a crediting and deductible mechanism) while that in NS provides the basis for singling out the greater amount to be payable; and (2) the return allowance in $\mathrm{N} \& \mathrm{~L}$ is calculated in a compounding manner while that in NS is non-compounding.

\section{For depreciable assets invested in $\mathrm{t}<\mathrm{T} 1$}

$$
\begin{aligned}
& R_{g}=\left\{(\delta+R-\pi)\left[(1-u Z)-\tau_{1}(1-u)(\delta+\pi)\left(1+\psi_{1}-R\right)^{T 1-t}-\tau_{2}(1-u)(\delta+\pi)\left(1+\psi_{2}-R\right)^{T_{2}-t}\right]\right\} / Y-\delta \\
& \text { with } \left.Y=\left[1-\tau_{1}\left(1+\psi_{1}-R\right)^{T 1-t}-\tau_{2}\left(1+\psi_{2}-R\right)^{T_{2}-t}\right)\right](1-u)
\end{aligned}
$$

\section{For depreciable assets invested in $\mathrm{T} 1<\mathrm{t}<\mathrm{T} 2$}

(18) $\mathrm{R}_{\mathrm{g}}=\left\{(\delta+\mathrm{R}-\pi)\left[(1-\mathrm{uZ})-\tau_{1}(1-\mathrm{u})-\tau_{2}(1-\mathrm{u})(\delta+\pi)\left(1+\psi_{2}-\mathrm{R}\right)^{\mathrm{T}_{2}-\mathrm{t}}\right]\right\} / \mathrm{Y}$

with $\left.Y=\left[1-\tau_{1}-\tau_{2}\left(1+\psi_{2}-R\right)^{T_{2}-t}\right)\right](1-u)$

For depreciable assets after T2 is reached

(19) $\mathrm{R}_{\mathrm{g}}=(\delta+\mathrm{R}-\pi)\left\{(1-\mathrm{uZ})-\left(\tau_{1}+\tau_{2}\right)(1-\mathrm{u})\right\} /\left((1-\mathrm{u})\left(1-\tau_{1}-\tau_{2}\right)\right)-\delta$

\section{For exploration,}

$$
R_{g}=(1+r)^{T-t}\left\{1-u-\omega \tau_{2}(1-u)\left(1+\psi_{2}-R\right)^{T_{2}-t}-\omega \tau_{1}(1-u)\left(1+\psi_{1}-R\right)^{T_{1}-t}\right\} /\left((1-u)\left(1-\tau_{1}-\tau_{2}\right)\right)
$$

For development,

(21) $\mathrm{R}_{\mathrm{g}}=(1+\mathrm{r})^{\mathrm{T}-\mathrm{t}}\left\{\left(1-\mathrm{uZ} \mathrm{Z}^{\prime}\right)-\tau_{2}(1-\mathrm{u})\left(1+\psi_{2}-\mathrm{R}\right)^{\mathrm{T}_{2}-\mathrm{t}}-\tau_{1}(1-\mathrm{u})\left(1+\psi_{1}-\mathrm{R}\right)^{\mathrm{T}_{1}-\mathrm{t}}\right\} /\left((1-\mathrm{u})\left(1-\tau_{1}-\tau_{2}\right)\right)$ 


\section{APPENDIX D}

\section{THE US OIL METRR MODEL}

The US METRR model for oil and gas covers the four main oil producing states: Arkansas, Colorado, Pennsylvania and Texas. Table 1 in the text summarizes the oil and gas fiscal regimes in these four states.

The general oil and gas fiscal regime in the US is relatively simple compared to that in Canada. There are three main taxes and a royalty combining both the federal and state levies: a federal income tax, a state income tax, a royalty levy depending on the ownership of the property and a state severance tax. Both royalty and severance tax are based on gross revenue net of transportation cost, and neither of them is sensitive to oil prices. ${ }^{37}$ Although both the royalty and severance tax are deductible for income tax purposes, the mechanism through which royalty and severance tax partially offset one another differs among the states.

The main issue here is how to interpret and model the geological and geophysical expenses as defined by the US Internal Revenue Services. The geological and geophysical expenses in the US are the counterparts of CEE and CDE in Canada. By referring to the US Internal Revenue Code, Sec. $167(\mathrm{~h}),{ }^{38}$ it is clear that:

"For tax years ending after August 8, 2005, any geological and geophysical expenses paid or incurred in connection with the exploration for, or development of, oil or gas within the United States (as defined in Code Sec. 638) may be amortized ratably over the 24-month period beginning on the date the expenses are paid or incurred. The amortization of these costs uses the half-year convention. That is, any payment incurred during the tax year is treated as paid or incurred on the mid-point of the tax year. This is the sole method for recovery of domestic geological and geophysical expenditures." ${ }^{39}$

Note that, as required by a special rule (see Sec. 167(h)(5)), ${ }^{40}$ the general amortization period of 24 months is extended to seven years for any "major integrated oil company."

We therefore model the exploration and development expenses equally as being amortized within seven years based on the original cost with a half-year convention. In the US model, to preserve compatibility with the treatment in Canadian provinces, we assume all the resources are owned by the state so as to ignore the fact that a large portion, if not the majority, of resource properties are owned by the private sector. This assumption also ignores the federal royalty that is payable on property owned by the federal government.

Two final notes concern the classification of depreciable assets and the effective state sales tax.

\footnotetext{
37 The severance tax may be reduced for certain new discovery wells or high-cost wells. But we apply only the general severance tax rate in our model.

38 Online source: http://www.taxalmanac.org/index.php/Internal_Revenue_Code:Sec._167._Depreciation

39 See Patrick A. Hennessee, "Oil and Gas: Federal Income Taxation," CCH, 2008, Chapter 9, page 147. http://books.google.com

${ }^{40}$ Online source: http://www.taxalmanac.org/index.php/Internal_Revenue_Code:Sec._167._Depreciation
} 
To single out the tax impact, the classification of capital cost allowance (CCA) for and the corresponding capital weights of depreciable assets used in the Canadian oil and gas model are adopted in the US oil and gas model. All these CCA classes, except for Class 41, exist in our US non-resource model 2010, which has been reconciled with the treatment by the Canadian Department of Finance. Therefore, the tax depreciation rate by asset class for manufacturing industry used in the US non-resource model is adopted in the US oil and gas model. Regarding Class 41, a capital class covering a broad range of assets used only by the resource sector in the Canadian CCA system, we assume it is a five-year property in the US MACRS system. This assumption is based on the finding of Hennessee: "Most oil and gas exploration, production, refining, and marketing equipment falls in the five-year property class." ${ }^{41} \mathrm{We}$ therefore modelled Class 41 as a five-year property following the corresponding MACRS approach with the half-year convention.

As for the effective state sales tax rate by class, the national average effective tax rate by class is first taken from our 2010 US non-resource model. The state effective sales tax rate by class is then estimated by multiplying the national counterpart by a factor of $X / 6$, where $X=$ the individual state statutory sales tax rate (combining both the state and sub-state sales tax rates) and 6 is the nationwide mode rate. For Class 41, which is used only by resource sectors, its national average effective sales tax rate is assumed to be the average of those for Classes 1 and 43. This is the same assumption for estimating the effective sales tax rate on Class 41 used in our Canadian oil and gas model for provinces where an un-harmonized provincial sales tax exists (e.g., British Columbia and Saskatchewan).

\section{The US METRR Model}

For exploration and development:

(1) $\mathrm{R}_{\mathrm{g}}=(1+\mathrm{r})^{\mathrm{T}}(1-\mathrm{uZ}) /\left\{\left[1-\tau^{\prime} \mathrm{P} /\left(\mathrm{P}-\mathrm{C}_{\mathrm{Q}}\right)\right](1-\mathrm{U})\right\}$

With $Z^{\prime}=$ present value of accumulated amortization allowance, $\tau^{\prime}=\tau+S(1-\tau)$ where $\tau=$ "statutory" royalty rate and $S=$ severance tax rate, or $\tau$ ' $=S+\tau(1-S)$ depending on the specific state, and $\left(\mathrm{P}-\mathrm{C}_{\mathrm{Q}}\right) / \mathrm{P}=$ rent to gross income ratio

\section{For depreciable assets:}

$$
R_{g}=(1+t)(r+\delta)[1-u Z+k(1-u) /(R+\alpha)] /(1-u)-\delta
$$

With $\mathrm{t}=$ effective state sales tax, $\mathrm{u}=\mathrm{U}_{\mathrm{f}}\left(1-\mathrm{U}_{\mathrm{s}}\right)+\mathrm{U}_{\mathrm{s}}, \mathrm{Z}=$ present value of the accumulated depreciation allowance, $\mathrm{k}=$ capital based tax rate, ${ }^{42}$ and $\alpha=$ the annual depreciable allowance.

\section{For inventory:}

(3) $\mathrm{R}_{\mathrm{g}}=(\mathrm{r}+0.5 * \mathrm{U} \pi) /(1-\mathrm{U})+\mathrm{k}$

It is assumed that 50 percent of firms are using FIFO and the rest LIFO.

[Note: The previous information shows that in the US, oil companies all use LIFO. But considering that the US is switching to FIFO completely, we keep the 50 percent assumption for now.]

${ }^{41}$ See Patrick A. Hennessee, "Oil and gas: federal income taxation," $\mathrm{CCH}, 2008$, page 551-552.

http://books.google.com 


\section{APPENDIX E}

\section{AUSTRALIA, BRAZIL, NORWAY AND THE UNITED KINGDOM: THE GENERIC METRR MODEL}

This appendix presents a generic model that includes key equations for estimating the marginal effective tax and royalty rate (METRR) for Australia, Brazil, Norway and the United Kingdom.

Owing to the significant variation among the fiscal regimes in these four countries, certain variables included in this generic model may be relevant to only one regime or two, and hence are set to be zero for the others. Tables B1 and B2 in Appendix B provide specific numbers, by country, for all the variables that appear in this generic model.

For exploration and development:

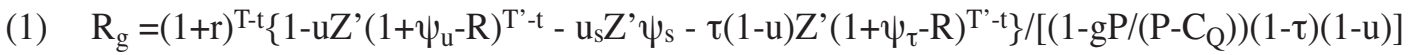

For depreciable assets:

(2) $\mathrm{R}_{\mathrm{g}}=(\delta+\mathrm{R}-\pi)\left[\left(1-\mathrm{uZ}-\mathrm{u}_{\mathrm{s}} \mathrm{Z} \psi_{\mathrm{s}}-\tau(1-\mathrm{u}) \mathrm{Z}_{\tau}\left(1+\psi_{\tau}-\mathrm{R}\right)^{\left(\mathrm{T}^{\prime}-\mathrm{T}\right) / 2}\right] /[(1-\tau)(1-\mathrm{u})]-\delta\right.$

Where (T'-T)/2 indicates the average number of years for depreciable assets to be written off for tax purposes. That is, it is assumed that depreciable assets take a shorter period to be written off compared to exploration expenses, given that the Australian PRRT regime requires exploration expenditures to be the last cost item to be written off for tax purposes.

For inventory:

(3) $\mathrm{R}_{\mathrm{g}}=[\mathrm{r}(1-\tau(1-\mathrm{u}))+\pi \mathrm{u}] /[(1-\tau)(1-\mathrm{u})]$

Note: Appendix E provides all the tax and non-tax parameters by country for variables appearing in this generic model. 


\section{ABOUT THIS PUBLICATION}

The School of Public Policy Research Papers provide in-depth, evidence-based assessments and recommendations on a range of public policy issues. Research Papers are put through a stringent peer review process prior to being made available to academics, policy makers, the media and the public at large. Views expressed in The School of Public Policy Research Papers are the opinions of the author(s) and do not necessarily represent the view of The School of Public Policy.

\section{OUR MANDATE}

The University of Calgary is home to scholars in 16 faculties (offering more than 80 academic programs) and 36 Research Institutes and Centres including The School of Public Policy. Under the direction of Jack Mintz, Palmer Chair in Public Policy, and supported by more than 100 academics and researchers, the work of The School of Public Policy and its students contributes to a more meaningful and informed public debate on fiscal, social, energy, environmental and international issues to improve Canada's and Alberta's economic and social performance.

The School of Public Policy achieves its objectives through fostering ongoing partnerships with federal, provincial, state and municipal governments, industry associations, NGOs, and leading academic institutions internationally. Foreign Investment Advisory Committee of the World Bank, International Monetary Fund, Finance Canada, Department of Foreign Affairs and International Trade Canada, and Government of Alberta, are just some of the partners already engaged with the School's activities.

For those in government, The School of Public Policy helps to build capacity and assists in the training of public servants through degree and non-degree programs that are critical for an effective public service in Canada. For those outside of the public sector, its programs enhance the effectiveness of public policy, providing a better understanding of the objectives and limitations faced by governments in the application of legislation.

\section{DISTRIBUTION}

Our publications are available online at www.policyschool.ca.

\section{DISCLAIMER}

The opinions expressed in these publications are the authors' alone and therefore do not necessarily reflect the opinions of the supporters, staff, or boards of The School of Public Policy.

\section{COPYRIGHT}

Copyright (C) 2012 by The School of Public Policy.

All rights reserved. No part of this publication may be reproduced in any manner whatsoever without written permission except in the case of brief passages quoted in critical articles and reviews.

\section{ISSN}

1919-112x SPP Research Papers (Print)

1919-1138 SPP Research Papers (Online)

\section{DATE OF ISSUE}

October 2012

\section{MEDIA INQUIRIES AND INFORMATION}

For media inquiries, please contact Morten Paulsen at 403-453-0062.

Our web site, www.policyschool.ca, contains more information about The School's events, publications, and staff.

\section{DEVELOPMENT}

For information about contributing to The School of Public Policy, please contact Courtney Murphy by telephone at 403-210-7201 or by e-mail at cmurphy@ucalgary.ca. 


\section{RECENT PUBLICATIONS BY THE SCHOOL OF PUBLIC POLICY}

THE GST AND FINANCIAL SERVICES: PAUSING FOR PERSPECTIVE

http:/ / policyschool.ucalgary.ca/ ?q=content/gst-and-financial-services-pausing-perspective Michael Firth and Kenneth McKenzie | September 2012

\section{ANNUAL GLOBAL TAX COMPETITIVENESS RANKING - A CANADIAN GOOD NEWS STORY}

http:/ / policyschool.ucalgary.ca/ ?q=content/ 2012-annual-global-tax-competitiveness-ranking-canadian-goodnews-story

Duanjie Chen and Jack Mintz | September 2012

DANCING WITH THE DRAGON: CANADIAN INVESTMENT IN CHINA AND CHINESE INVESTMENT IN CANADA http:/ / policyschool.ucalgary.ca/?q=content/ dancing-dragon-canadian-investment-china-and-chineseinvestment-canada

Josephine Smart | September 2012

SUPPORT FOR BUSINESS R\&D IN BUDGET 2012: TWO STEPS FORWARD AND ONE BACK http:// policyschool.ucalgary.ca/ sites/default/files/research/j-lester-budget-2012-communique-final.pdf John Lester | August 2012

SIZE, ROLE AND PERFORMANCE IN THE OIL AND GAS SECTOR http:// policyschool.ucalgary.ca/ sites/default/files/research/mansell-oil-and-gas-july-18.pdf R.L. Mansell, J. Winter, M. Krzepkowski, M.C. Moore | July 2012

THE BIG AND THE SMALL OF TAX SUPPORT FOR R\&D IN CANADA http:// policyschool.ucalgary.ca/sites/default/files/research/k-mckenzie-rd-tax-final.pdf Kenneth J. McKenzie | July 2012

HOW YOU PAY DETERMINES WHAT YOU GET: ALTERNATIVE FINANCING OPTIONS AS A DETERMINANT OF PUBLICLY FUNDED HEALTH CARE IN CANADA

http:/ / policyschool.ucalgary.ca/?q=content/ how-you-pay-determines-what-you-get-alternative-financingoptions-determinant-publicly-funded-health-care-canada.pdf Ronald Kneebone | June 2012

SUPPLY MANAGEMENT: PROBLEMS, POLITICS - AND POSSIBILITIES

http:/ / policyschool.ucalgary.ca/?q=content/ supply-management-problems-politics-and-possibilities.pdf Martha Hall Findlay | June 2012

POLICY OPTIONS FOR REDUCING DIETARY SODIUM INTAKE http:/ / policyschool.ucalgary.ca/ ?q=content/ policy-options-reducing-dietary-sodium-intake.pdf Lindsay McLaren | June 2012

A WHITE PAPER* ON REFORMING CANADA'S TRANSPORTATION POLICIES FOR THE 21ST CENTURY http:/ / policyschool.ucalgary.ca/?q=content/ white-paper-reforming-canadas-transportation-policies-21scentury.pdf

Brian Flemming | June 2012 